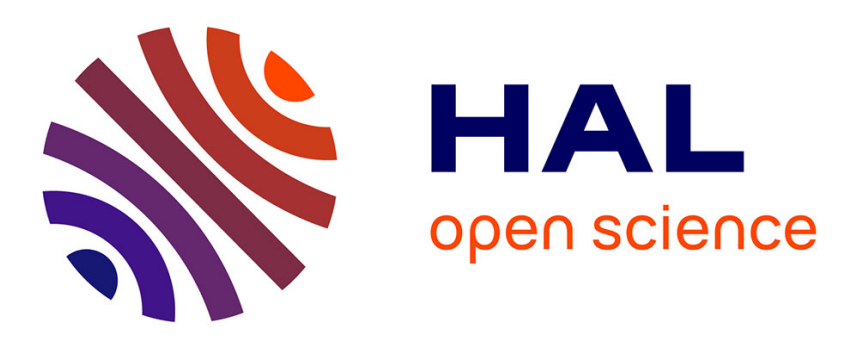

\title{
Integrative taxonomy of an arctic bumblebee species complex highlights a new cryptic species (Apidae: Bombus)
}

Baptiste Martinet, Thomas Lecocq, Nicolas Brasero, Maxence Gérard, Klara Urbanova, Irena Valterová, Jan Ove Gjershaug, Denis Michez, Pierre Rasmont

\section{To cite this version:}

Baptiste Martinet, Thomas Lecocq, Nicolas Brasero, Maxence Gérard, Klara Urbanova, et al.. Integrative taxonomy of an arctic bumblebee species complex highlights a new cryptic species (Apidae: Bombus). Zoological Journal of the Linnean Society, 2019, 187 (3), pp.599-621. 10.1093/zoolinnean/zlz041 . hal-02501083

\section{HAL Id: hal-02501083 \\ https://hal.univ-lorraine.fr/hal-02501083}

Submitted on 8 Dec 2020

HAL is a multi-disciplinary open access archive for the deposit and dissemination of scientific research documents, whether they are published or not. The documents may come from teaching and research institutions in France or abroad, or from public or private research centers.
L'archive ouverte pluridisciplinaire HAL, est destinée au dépôt et à la diffusion de documents scientifiques de niveau recherche, publiés ou non, émanant des établissements d'enseignement et de recherche français ou étrangers, des laboratoires publics ou privés. 
6

7
Integrative taxonomy of an arctic bumblebee species-complex highlights a new cryptic species (Apidae, Bombus)

Running title: Systematics of an arctic bumblebee species complex

\section{Abstract}

While bumblebees have been the focus of much research, the taxonomy of many species groups is still unclear, especially within circum-polar species. Delimiting species based on multisource datasets provides a solution to overcome current systematic issues of closely related populations. Here, we use an integrative taxonomic approach based on novel genetic and ecochemical datasets to resolve the taxonomic status of Bombus lapponicus and B. sylvicola. Our results support the conspecific status of B. lapponicus and B. sylvicola and that the low gradual divergence around the Arctic Circle between Fennoscandia and Alaska does not imply speciation in this species complex. Therefore, based on our molecular and morphological analyses, we propose to assign the sub-specific status: B. lapponicus lapponicus comb. nov. from Fennoscandia and W-Siberia and B. lapponicus sylvicola comb. nov. from Alaska and Yukon. Moreover, our analyses reveal a new cryptic arctic species in the B. lapponicus complex: B. (Pyrobombus) interacti sp. nov. Martinet, Brasero \& Rasmont from Alaska.

Keywords: Bombus - Circum-polar species - Cryptic species - Integrative taxonomic approach 


\section{Introduction}

Most biodiversity hotspots are found in tropics with a pattern of increasing biodiversity from the poles to the equator (Brown 2014). However, the highest latitudes have many conspicuous and endemic species living under some of the most extreme conditions on Earth (Lomolino et al. 2010; Botero et al. 2014). This arctic and boreal biodiversity has been shaped by speciation processes driven by (i) the cold climate and local adaptations to environmental harshness linked to arctic ecology and by (ii) spatial and temporal geographic patterns specifically the heterogeneity of resource patches as landscape focal points (Chapin \& Körner 1995; Willig et al. 2003).

Potential speciation processes between allopatric populations inhabiting different continents around the Arctic Circle have been the focus of much research, and has been the subject of long-standing debates (Reinig 1937; Irwin et al. 2001a, 2005; Päckert et al. 2005; Monahan et al. 2012; Alcaide et al. 2014). Indeed, the topography of the continents around the North Pole could lead to the formation of a chain of intergrading populations (e.g. across Eurasia) connecting two reproductively isolated taxa (e.g. across the Atlantic region); the so called ring species (Stresemann \& Timofeeff-Ressovsky 1947; Irwin et al. 2001a) or Artenkreis speciation process (sensu Rensch 1933). In this process, each intergrading population is able to reproduce with immediately adjacent populations, but not with the more remote populations through a set of parapatric speciation processes (Irwin et al. 2001b). This could be explained for instance by small interpopulational variations of the species mate recognition system which prevent the specific recognition between individuals of distant populations or by ecological differentiation (Rensch 1933; Stresemann \& Timofeeff-Ressovsky 1947). Several cases of ring speciation process were emphasized in birds, such as for Phylloscopus trochiloides in Siberia (Alström 2006) or Melospiza melodia in Sierra Nevada (Patten \& Pruett 2009).

Bumblebees (Hymenoptera: Apidae) are cold-adapted species, an adaptation that enable them to live in some of the highest latitude and altitude ecosystems and reach high diversity in the arctic and boreal regions (Shamurin 1966; Kevan 1973; Williams 1998; Michener 2007; Biella et al. 2017). As a result, bumblebees are an excellent model group to explore speciation processes in circum-polar areas with disjunct distributions (Williams et al. 2015). There is some evidence that a circum-polar speciation process could have shaped the Bombus lapponicus sylvicola complex. In the East-Palaearctic, Skorikov (1922) described a multitude of forms across the circum-boreal region. These taxa are connected by a long set of potential interbreeding populations around the Arctic Circle (Skorikov 1922). When comparing these 
forms to American taxa, Pittioni (1942) pointed out a possible ring speciation process by highlighting the variability of $B$. lapponicus with increased melanization process in the East (Skorikov 1937). These different forms could be due to the fragmentation of the arctic habitat. More recently, several authors have questioned the taxonomic relationship which connects sylvicola and lapponicus (Thorp et al. 1983; Savard 2009; Williams et al. 2014). Among these circum-polar populations, only B. lapponicus, B. sylvicola, B. glacialis (Novaya Zemlya, Wrangel Island), and B. karaginus (Kamchatka) are currently recognized as valid species (Proshchalykin \& Kupianskaya 2005; Williams et al. 2014; Potapov et al. 2017). Though, it has been suggested that B. lapponicus and B. sylvicola could be conspecific (Sladen 1919; Skorikov 1922, 1937; Pittioni 1942, 1943; Thorp 1962; Thorp et al. 1983), data from 16S and cytochrome oxidase I (COI) gene fragments support two divergent taxa in phylogenetic analyses (Hines et al. 2006; Cameron et al. 2007). However, a comparison of all available data leaves the taxonomic status of this group uncertain.

The systematics of bumblebees remains challenging (Bertsch \& Schweer 2012; Lecocq et al. 2015a; Williams et al. 2012) due to the limitations of morphological traits as diagnostic characters (Bickford et al. 2007; Batalha-Filho et al. 2010; Carolan et al. 2012). The development of integrative taxonomy involving a consensus between several independent alternative traits (e.g. molecular, eco-chemical traits) provides a solution to help resolve bumblebee systematics at the species level (Estoup et al. 1996; Ings et al. 2010; Leaché \& Fujita 2011; Engel 2011; Lecocq et al. 2015c). Here, we propose to investigate the ring speciation process focusing on the most common circum arctic bumblebee taxa complex: Bombus (Pyrobombus) lapponicus (Fabricius, 1793) (North Scandinavia, W-Siberia) - B. (Pyrobombus) sylvicola Kirby, 1837 (North America). We address the taxonomic uncertainties that exist between these distant populations (Williams 1998; Williams et al. 2014; Cameron 2007) and we present new morphometric, genetic and eco-chemical evidence to resolve the taxonomic status of $B$. lapponicus and B. sylvicola using an integrative taxonomic approach.

\section{Material and Methods}

\section{Sampling and morphological identification}

Bombus lapponicus is a common Euro-Siberian boreo-alpine species (Fig. 1A). Its geographic distribution extends from the north of the taiga to the tundra (except in Taymyr peninsula, N-Siberia) between the 65th and 70th parallels in Europe and the 60th and 72nd parallels in Siberia (Løken 1973; Pekkarinen et al. 1981; Pekkarinen 1982). Bombus sylvicola is a widespread species from the northern and western mountains of North America (Fig. 1B). This Nearctic taxon is morphologically very similar to B. lapponicus (Williams et al. 2014). In 
North America, two forms of sylvicola have been described: one with the metasomal T2-3 red from the Rocky Mountains and the second with T2-3 mainly black from the Sierra Mountains. DNA barcoding supports the two principal color forms of sylvicola in North America as conspecific including the doubtful taxon named gelidus from Alaska (Cresson 1878) which has black hairs on the face and on the sides of the thorax (Williams et al. 2014).

We were able to sample females and males of B. lapponicus from North Scandinavia $(n=12)$ and Siberia $(n=10)$, B. sylvicola from Northern Alaska $(n=29)$ and Yukon $(n=4)$ (Fig. S1). For comparison, we used the phylogenetically closely related species B. (Pyrobombus) monticola scandinavicus ( $n=9$ ) from North Scandinavia (Cameron et al. 2007), Bombus (Pyrobombus) bimaculatus $(n=10)$ from Canada, Bombus (Pyrobombus) ephippiatus $(n=6)$ from Biobest NA (Chiapas), Bombus (Pyrobombus) konradini ( $n=5)$ from Italy, Bombus (Pyrobombus) glacialis $(n=1)$ from Novaya Zemlya, Bombus (Pyrobombus) melanopygus $(n=2)$ from California and as an outgroup Bombus (Bombus) terrestris $(n=14)$ from Italy, France, Sweden, Belgium and Scotland. The individual bumblebee specimens were killed by freezing at $-20^{\circ} \mathrm{C}$.

Specimens were identified based on their morphology with identification keys such as Løken (1973); Williams et al. (2014). A total of 147 bumblebees, collected between 2013 and 2018 in Europe, Siberia and Northern America, were analyzed (Table S1). For a first identification, we performed a comparative table (male and female) gathering diagnostic characters and color patterns for the studied specimens to compare morphological characters within the lapponicus-sylvicola complex.

\section{Genetic differentiation}

In this study, we sequenced two genes commonly used to assess the specific status in bumblebees (Pedersen 2002; Hines et al. 2006; Cameron et al. 2007; Lecocq et al. 2013a,b): the mitochondrial cytochrome oxidase 1 gene (COI), and the nuclear phosphoenolpyruvate carboxykinase gene (PEPCK). DNA extraction protocol, polymerase chain reaction, amplification reactions, sequencing procedures and alignment of DNA sequences were performed according to the method described in Lecocq et al. (2015a, c). COI and PEPCK sequences were deposited on GenBank (Table S1). For each gene, we carried out phylogenetic analyses to investigate genetic differentiations between B. lapponicus and B. sylvicola. We performed maximum likelihood (ML) and Bayesian (MB) analyses. For all methods, the PEPCK gene was partitioned into two exons and two introns to explore the best substitution model. COI fragment and each nuclear exon were partitioned by base positions (first, second, and third nucleotide). For each dataset, we used JModelTest Server 2.0 (Posada 2008) with the 
corrected Akaike information criterion (AICc) to find the best-fitting substitution models. The models chosen were: (i) for COI : GTR+I (first position), TIM2+I (second position), $\mathrm{TrN}+\mathrm{G}$ (third position); (ii) for PEPCK first intron: TPM1 uf +I ; (iii) for PEPCK exon $1: \mathrm{HKY}+\mathrm{I}$ (first position), JC (second position), TrN+I (third position) ; (iv) for PEPCK second intron : $\mathrm{TrN}+\mathrm{I}$; (v) for PEPCK exon 2: JC (first, second, and third positions). Selected models which are not implemented in MrBayes were substituted by the closest over-parameterized model. For ML analyses, we performed ten independent runs in GARLI 2.0 for both genes (Zwickl 2006); the topology and-ln L were the same among replicates. Only the run with the highest likelihood was saved. We assessed statistical significance of nodes with 10,000 nonparametric bootstrap replicates. We considered a topology well supported (high confidence) when the bootstrap value (branch supports) was higher than 85\% (Hillis \& Bull 1993). We carried out MB analyses with MRBAYES 3.1.2 (Ronquist \& Huelsenbeck 2003). We achieved ten independent analyses for each gene (100 million generations, four chains with mixed models, default priors, saving trees every 100 generations). Then we removed the first ten million generations as burn-in procedure. A majority-rule 50\% consensus tree was constructed. Only branch supports (topologies) with high posterior probabilities $(\geq 0.95)$ were considered statistically significant (Wilcox et al. 2002). Trees were rooted on B. terrestris (outgroup species). For genetic analyses, we used clustering computers provided by the Consortium des Équipements de Calcul Intensif (CÉCI, F.R.S.-FNRS).

To recognize a species threshold, we used a Bayesian implementation of the general mixed Yule-coalescent model (bGMYC) based on COI tree (Reid \& Carstens 2012, see Lecocq et al. 2015c). These analyses were performed with "bGMYC" R packages (Reid \& Carstens 2012). A range of probabilities $>0.95$ was considered as strong evidence that taxa were conspecific while a range of probabilities $<0.05$ suggested that taxa were heterospecific (Reid \& Carstens 2012). We performed a phylogenetic analysis with BEAST 1.7.4 (Drummond et al. 2012) to generate ultrametric trees using a phylogenetic clock model to generate a posterior distribution of trees (length of the MCMC chain: 100 million generations). The first million sampled trees were treated as burn-in, using the maximum clade credibility method and setting the posterior probability limit to 0 . We based the bGMYC analysis on 1000 trees sampled every 10,000 generations. For each of these 1000 trees, the MCMC was made of 100,000 generations, discarding the first 90,000 as burn-in and sampling every 100 generations. Posterior probability distributions have been applied against the first sample tree. 
In the genus Bombus, conspecific individuals share the same recognition signals to recognize each other as sexual partners (Calam 1969). We focused on the most studied reproductive trait involved in the bumblebee pre-mating recognition (Svensson 1980; Ayasse \& Jarau 2014; Baer 2003): the cephalic labial gland secretions (CLGSs). CLGSs are commonly used for species discrimination in bumblebees (Rasmont et al. 2005; Terzo et al. 2005; Bertsch \& Schweer 2012). CLGSs are synthesized de novo by cephalic labial glands (Žácek et al. 2013) in the head of bumblebee males and are known to be species-specific (Lecocq et al. 2015c). CLGSs consist of a complex mixture of (mainly aliphatic or isoprenoid) compounds, with variable main compounds (Coppée et al. 2008; Lecocq et al. 2011). By main compounds, we mean compounds that have the highest relative proportion (RA) among all compounds of CLGSs at least in one individual of the taxon.

We extracted CLGS in $400 \mu \mathrm{l}$ of $\mathrm{n}$-heptane, according to the method described by De Meulemeester et al. (2011). Samples were stored at $-40^{\circ} \mathrm{C}$ prior to the analyses. For $B$. lapponicus, B. monticola, and B. bimaculatus, the data of CLGS compositions are the same as those described by Martinet et al. (2017) (Table S2). For B. terrestris, we used the CLGS dataset described in Lecocq et al. (2016).

The qualitative composition of the CLGS was determined by gas chromatography-mass spectrometry using a Finigan GCQ quadrupole system (GC/MS) with a non-polar DB-5 ms capillary column [5\% phenyl (methyl) polysiloxane stationary phase; column length $30 \mathrm{~m}$; inner diameter $0.25 \mathrm{~mm}$; film thickness $0.25 \mu \mathrm{m}$ ]. All samples of CLGS were quantified with a gas chromatograph Shimadzu GC-2010 system (GC-FID) equipped with a non-polar SLB-5 ms capillary column [5\% phenyl (methyl) polysiloxane stationary phase; column length $30 \mathrm{~m}$; inner diameter $0.25 \mathrm{~mm}$; film thickness $0.25 \mu \mathrm{m}$ ] and a flame ionization detector. The composition of CLGS was analyzed according to the protocol described in Lecocq et al. (2015c). All compounds for which the relative abundance was recorded as less than $0.1 \%$ for all specimens were excluded from the analysis (De Meulemeester et al. 2011). The data matrix for each taxon was based (Table S2) on the alignment of each relative proportion of compound between all samples performed with GCAligner 1.0 (Dellicour \& Lecocq 2013a,b). To facilitate the alignment of compounds and the identification, before each sample injection, a standard mixture of alkenes (Kovats) from $\mathrm{C} 10$ (decane) to $\mathrm{C} 40$ (tetracontane) was injected. We calculated Kovats indices with GCKovats 1.0 according to the method described by Dellicour \& Lecocq $(2013 \mathrm{a}, \mathrm{b})$.

Statistical analyses 

Development Core Team, 2016) to detect CLGS differentiations. We transformed data $[\log (x$

$+1)$ ] to reduce the great difference of abundance between highly and lowly concentrated compounds. We used a principal component analysis (PCA, R-package MASS, Venables \& Ripley 2002) based on correlation distance matrices, and a clustering method computed with the unweighted pair-group method with average linkage (UPGMA) based on Canberra distance matrices (RA of each compound) (R package ape; Paradis et al. 2004). We assessed the uncertainty in hierarchical cluster analysis using p-values calculated by multiscale bootstrap resampling with 100,000 bootstrap replications (significant branch supports $>0.85$ ) (R package pvclust, Suzuki \& Shimodaira 2011). We also assessed CLGS differentiations between taxa by performing a multiple response permutation procedure (MRPP, R package vegan, Oksanen et al. 2011) based on groups identified by hierarchical cluster analysis. When a significant difference was detected, pairwise multiple comparisons were performed with an adjustment of p-values (Bonferroni correction) to avoid type I errors. To determine specific compounds of each taxon (i.e. indicator compounds), the indicator-value (IndVal) method was used (Claudet et al. 2006; Dufrêne \& Legendre 1997). This value is the product of relative concentration and relative occurrence frequency of a compound within a group. The statistical significance of an indicator compound $(>0.7)$ was evaluated with a randomization procedure (Dufrêne \& Legendre 1997).

\section{Data integration and decision framework}

We based our species delimitation hypothesis on the method performed by Lecocq et al. (2015a), derived from the integrative approach established by Schlick-Steiner et al. (2010) according to the unified species concept (De Quieroz 2007). With our approach, criteria are not balanced, and the assignment of species status is allocated by unanimity of all criteria to avoid species over-estimation (Padial et al. 2010; Schlick-Steiner et al. 2010). The specific status was assigned if this taxon: (i) was genetically differentiated in all genetic markers (i.e. potential unique haplotypes), (ii) constituted a monophyletic group with high branch support, and (iii) was significantly differentiated in CLGS compositions (including IndVal indicator compounds, MRPP test, bootstrap values > 0.85). This conservative approach could lead to underestimation of the species differentiation but reduces the taxonomic inflation (Lecocq et al. 2015a; Williams et al., 2015). To highlight taxa with infra-specific-level differentiation, we assigned the subspecies status to phenotypically distinct allopatric populations with differentiations in some traits to highlight these populations displaying of such a differentiation. This approach reduces 
the risk of underestimating taxonomic diversity (Hawlitschek et al. 2012; Ennen et al. 2014; Lecocq et al. 2015a, c).

\section{Geometric morphometrics}

As fresh material of B. gelidus was not available for molecular and chemical analyses, we run an additional study to test the similarity between gelidus type material and other lapponicus group taxa. The right forewings of 44 queens were photographed using an Olympus SZH10 microscope an AF-S NIKKOR 18-105 millimetres (Shinjuku, Japan) and GWH10XCD oculars coupled with a Nikon D200 camera: 39 queens of B. lapponicus (including specimens of B. lapponicus lapponicus $(\mathrm{n}=14)$ and B. lapponicus sylvicola $(\mathrm{n}=29))$ and 1 queen of B. gelidus (holotype). For B. gelidus, in the Smithsonian National Museum of Natural History, Massachusetts Agricultural College and United States National Museum, there are 1 queen, 14 workers and 1 male labelled "Cotype" by Franklin (1912). All these specimens should not be part of the typical series and have been erroneously labeled. These specimens were collected later and in other areas than the only holotype described by Cresson (1878). After examination, we consider that these specimens belong to B. lapponicus sylvicola. All easily available material has been evaluated, including specimens from the Aleutian Islands. We have revised the type series, including the "false type anachronic inclusion". Wing shapes were captured by digitizing two-dimensional Cartesian coordinates of 18 landmarks (Fig. S2) on wing veins with tps-DIG v2.17 (Rohlf 2013a, b). The landmark configurations were scaled, translated, and rotated against the consensus configuration using the GLS Procrustes superimposition method to remove all non-shape differences and to separate the size from shape components of the form (Rohlf \& Slice 1990; Bookstein 1991). The superimposition was performed using R functions of the package geomorph (Adams \& Otárola-Castillo 2013). Each wing was digitized twice by the same experimenter (MG), to account for measurement error. The aligned landmark configurations were projected into the Euclidean space tangent to the curved Kendall's shape space to aid further statistical analyses. The correlation coefficient between the Procrustes distances in the shape space and the Euclidean distances in the linear tangent space equalled 1.00. This indicates that the curvature of the shape space around our data was negligible (Rohlf 1999). The least-squares regression slope through the origin (0.999) and the correlation coefficient between the two distances were calculated with tps-SMALL v1.25 (Rohlf 2013c).

After checking of application assumptions, PerMANOVA (Permutational analysis of variance) analyses were performed to assess wing size and wing shape differences between 
groups. A PCA was performed to assess shape variation among the different groups, using the geomorph function "plotTangentSpace" and to visualize potential differentiation between taxa.

Prior to the assignment of the holotype queen B. gelidus, shape variation within the reference dataset and discrimination of the different taxa was assessed by Linear Discriminant Analyses (LDA) of the projected aligned configuration of landmarks. These analyses were performed at species level as a priori grouping by using the software $\mathrm{R}$ version 3.0.2. The effectiveness of the LDA for discriminating taxon was assessed by the percentages of individuals correctly classified to their original taxon (hit-ratio, HR) in a leave-one-out crossvalidation procedure based on the posterior probabilities of assignment. Given the observed scores of an "unknown", the posterior probability (pp) equals the probability of the unit to belong to one group compared to all others. The unit is consequently assigned to the group for which the posterior probability is the highest (Huberty \& Olejnik 2006). Taxonomic affinities of the holotype queen $B$. gelidus were first assessed based on their score in the predictive discriminant space of shapes. After superimposition of the landmark configurations, aligned coordinates of the specimens from the reference dataset were used to calculate the LDA. A unique superimposition of both the reference dataset and the assigned specimens is sometimes disregarded while it is of primary importance because GLS Procrustes superimposition is sampling dependent. We included a posteriori the holotype queen B. gelidus in the computed LDA space as "unknown” specimen and calculated their score. Assignments of the holotype B. gelidus were estimated by calculating the Mahalanobis Distance between "unknown" and group mean of each taxon. We also calculated posterior probabilities of assignment to confirm the assignment to one taxon.

\section{Results}

\section{Genetic analyses}

A total of $938 \mathrm{bp}$ from the COI gene and $925 \mathrm{bp}$ from PEPCK were obtained. All phylogenetic analyses (ML and MB) on each genetic dataset showed a similar topology and identical phylogenetic differentiation (Fig. 2). As expected, we found a less structured tree in the PEPCK gene for the lapponicus-sylvicola group. For the two gene fragments, the lapponicus-sylvicola group resulted in two lineages: (a) one comprising all lapponicus and a part of sylvicola specimens (group A, 1.92\% of divergence between COI sequences) and (b) a second lineage comprising the second part of sylvicola (group B) (Fig. 2). While genetic analyses based on the mitochondrial gene COI showed a slightly supported divergence between B. lapponicus and B. sylvicola group A (Fig. 2B), there was no differentiation between these two taxa for the nuclear marker PEPCK (Fig. 2A). In COI sequences, 18/938 (1.92\%) of 
phylogenetically informative nucleotide sites are uniquely diagnostic to separate sylvicola group A and lapponicus. These divergence estimations between sylvicola part A and lapponicus were performed excluding specimens of sylvicola group B forming a separate clade (see below). Other species-specific branches were supported by high bootstrap values (bootstrap > 90\%).

Our genetic analyses revealed a new cryptic taxon from Alaska in our sylvicola samples (part B): B. interacti sp. nov. Martinet, Brasero \& Rasmont closely similar and co-occurring with sylvicola in Alaska. This new taxon was strongly supported as a monophyletic group with both COI (8.74 \% of sequence divergence from sylvicola part A and 9.80\% from monticola) and PEPCK (> 1\% of divergence from monticola and sylvicola) analyses. Contrary to the COI marker, the phylogenetic affinities inside the group including interacti sp. nov., monticola, and konradini were not resolved with the nuclear PEPCK fragment (Fig. 2A). PEPCK and COI sequences of $B$. interacti sp. nov. have been blasted to NCBI Genbank database. Sequences matched most closely to the studied species complex lapponicus-sylvicola-monticola but with no complete identity (99\% of identity and $100 \%$ of query cover for PEPCK, $96 \%$ of identity and $97 \%$ of query cover for COI from B. monticola in Genbank). In our phylogenetic analyses, B. interacti sp. nov. differs significantly from B. melanopygus and B. glacialis (high branch supports and posterior probabilities, Fig. 2A, 2B).

The bGMYC analysis (Fig. 3) highlighted nine entities with low probabilities $(<0.05)$ to be conspecific with the other ones. These results matched with results from the phylogenetic analyses of COI gene (ML, MB analyses). Overall, the bGMYC suggested the delimitation of seven prospective species $(\mathrm{p}<0.05$ ): (i) B. terrestris (bGMYC conspecificity probabilities between individuals included in the group, $\mathrm{p}>0.12-1$ ), (ii) B. ephippiatus ( $\mathrm{p}>0.97-1$ ), (iii) $B$. interacti sp. nov. ( $\mathrm{p}>0.98-1)$, (iv) B. monticola $(\mathrm{p}>0.47-1)$, (v) B. bimaculatus $(\mathrm{p}>0.89-1)$, (vi) B. konradini ( $\mathrm{p}>0.99-1$ ), (vii) a group with sylvicola and lapponicus ( $\mathrm{p}>0.07-1$ ), (viii) a group with B. glacialis and (ix) a group with B. melanopygus. The pairwise matrix (Fig. 3) showed a non-significant heterospecificity threshold between lapponicus and sylvicola $(\mathrm{p}>$ $0.05)$.

\section{Chemical analysis}

A total of 134 compounds were detected in the CLGS of the different studied species: 60 identical compounds were detected and shared by B. sylvicola (group A) and B. lapponicus, 57 compounds for $B$. monticola, 39 compounds for B. bimaculatus, 50 compounds for $B$. konradini, 25 for B. terrestris, 45 compounds for B. ephippiatus, 64 compounds for $B$. interacti sp. nov. (= B. sylvicola group B). Our chemical analyses showed qualitative and quantitative differentiations between all taxa including specific main compounds except between $B$. 
lapponicus and B. sylvicola group A where the CLGS composition was statistically identical (Appendix S2). Chemical analyses supported the presence of another taxon in the sylvicola samples from Alaska (B. interacti sp. nov.).

The main compounds detected were (a) the geranyl citronellol $(55.28 \%-77.30 \%)$ shared by B. sylvicola and B. lapponicus; (b) the hexadec-9-enyl acetate $(45.91 \%-61.74 \%$ ) for B. monticola and B. konradini (48.36\%-54.71\%); (c) Ethyl octadec-9-enoate for B. konradini (7.43\%-9.14\%); (d) the hexadec-9-enyl acetate $(20.55 \%-40.63 \%)$ and the geranyl geranyl acetate $(25.98 \%$ - 39.42\%) for B. bimaculatus, (e) the dihydrofarnesol $(19.08 \%-40.45 \%)$ for B. terrestris, (f) the hexadecanoic acid (19.03\%-31.63\%) for B. ephippiatus, and (g) the citronellyl hexadec-9-enoate $(12.37 \%-23.57 \%)$ for B. interacti sp. nov. (Tables 1 and S2). Statistical analyses supported the differentiation (MRPP, $A=0.6973, T=0.1759$, all $\mathrm{p}<0.001$ ) of seven groups also supported by high multiscale bootstrap resampling values (Cluster and ACP Fig. 4): (a) B. monticola (pairwise test, p < 0.01), (b) B. konradini (pairwise test, p < 0.01) (c) B. bimaculatus (pairwise test, $\mathrm{p}<0.01$ ), (d) B. ephippiatus (pairwise test, $\mathrm{p}<0.01$ ), (e) B. terrestris (pairwise test, $\mathrm{p}<0.01$ ), (f) B. sylvicola group $\mathrm{A}+$ B. lapponicus (pairwise test, $\mathrm{p}<$ 0.01 ), and (g) B. interacti sp. nov. (pairwise test, $\mathrm{p}<0.01$ ). No statistical differentiation was found in the statistical hypothesis test and in hierarchical clustering between lapponicus and sylvicola group A (Fig. 4; MRPP, A=0.004641, T=0.1577, p =0.30). Several significant and specific indicator compounds were revealed by the IndVal method (IndVal > 0.70), but no compound has been identified to discriminate B. lapponicus to B. sylvicola (Table S2).

Wing size and shape analyses

No significant difference in centroid size was found among the different taxa $(F=2.73$; $\mathrm{p}$-value $=0.08)$. However, significant differences in wing shape were found among the different taxa (perMANOVA, $\mathrm{F}=1.83$; $\mathrm{p}$-value $=0.006$ ). Pairwise perMANOVA tests have shown a significant difference between $B$. lapponicus and B. interacti sp. nov. $(\mathrm{F}=2.44$; p-value $=$ $0.004)$ and between $B$. interacti sp. nov. and B. gelidus $(\mathrm{F}=1.96$; p-value $=0.035)$ while no difference was detected between B. lapponicus and B. gelidus $(\mathrm{F}=1.21$; p-value $=0.32)$. PCA plot highlights two distinct groups (Fig. 5): (i) one cluster gathering specimens of B. lapponicus, B. sylvicola and B. gelidus, (ii) a second cluster with specimens of B. interacti sp. nov. The two groups B. lapponicus and B. sylvicola were not discriminated in the PCA and LDA while $B$. interacti group is strongly differentiated. In the morphometric space defined by the PCA, the specimen of gelidus is undoubtedly clustered with the group of the B. lapponicus (Fig. 5). Aposteriori assignment of the holotype B. gelidus in the discriminant shape space (LDA) allows 
a reliable specific attribution. This analysis reveals that this specimen is assigned to $B$. lapponicus species (Mahalanobis Distance to B. sylvicola group $=1.44 ; \mathrm{pp}=1$ ).

Morphological diagnosis

For this morphological comparison, we assess only males and queens (minimum 15 individuals per taxon according to the availability of specimens). Except for the coloration of the face which is black for lapponicus and yellow for sylvicola, no diagnostic character was found to discriminate lapponicus from sylvicola based on our morphological examinations (Table 2). Concerning sylvicola, we found two discrete morphotypes among our sampling from Alaska (corresponding to sylvicola part A and sylvicola part B (= Bombus interacti sp. nov.) in our molecular analyses) that could be separated by several diagnostic characters. Bombus interacti sp. nov. males differed from sylvicola in the pubescence of the tibia which is hairier for sylvicola (Fig. 6). No difference in the genitalia's structures was detected. For female, $B$. interacti sp. nov. differed from sylvicola in the face clypeus coloration: black with intermixed dark yellow hair for interacti sp. nov. and yellow for sylvicola. Besides, the density of pubescence of the tergite 5 is higher for $B$. interacti sp. nov. and the yellow coloration of collar not reaching the bases of the legs. (Fig. 6). Moreover, the morphological character "shape and pubescence of basitarsus", used by Gjershaug et al. (2013) to distinguish B. lapponicus from B. monticola, does not allow distinction of $B$. interacti sp. nov. from B. monticola and this character is similar between lapponicus and sylvicola. From B. glacialis, females of B. interacti sp. nov. differ for several characters: (i) labral furrow (narrow for B. interacti sp. nov., broad for B. glacialis); (ii) punctuations into the labral furrow (very few in B. glacialis); (iii) dorsal furrow of gena which is weakly developed in B. glacialis. Males of B. interacti sp. nov. differ from B. glacialis for: (i) the color of the vertex and the clypeus (yellow for B. glacialis); (ii) hind basitarsus (gradually narrowing towards basal part for B. glacialis); (iii) punctuations into the labral furrow (very dense for $B$. interacti and labrum covered with reddish bristles at the front part).

Taxonomic status: Description of the new species B. interacti Martinet, Brasero \& Rasmont sp. nov. and synonymy of lapponicus and sylvicola

Family APIDAE Latreille, 1802

GENUS BOMBUS Latreille, 1802

Bombus (Pyrobombus Dalla Torre 1880) interacti sp. nov. Martinet, Brasero \& Rasmont, 2018 
Type species: Bombus interacti sp. nov. Martinet, Brasero \& Rasmont, 2018. By subsequent diagnosis.

\section{Description:}

Females. Length 15-18 mm.

Coat color. Face and vertex densely pubescent with black hairs intermixed with few yellowishgreyish hairs. Thorax with a collare as large as $1 / 3$ of the thorax length, with few intermixed black hairs at front of tegulae; scutellare as large as 1/4 of the thorax length. The hairs of the scutellare are shaped in two oblique tufts. Pleura covered with greyish hairs on the anterior third, intermixed with black in front of the tegulae; mesopleura with intermixed grey and black hairs; metapleura are mostly black. Wings are not particularly dark (contrary to B. gelidus). T1 mostly covered with grayish hairs, intermixed with black hairs in the middle. T2 covered with red hairs, intermixed with few black ones on the sides and with numerous grayish ones at the middle of anterior margin. T3 all red with few grayish hairs at the middle of posterior margin. T4 mostly covered with grayish hairs, with very few red hairs at the anterior margin and black ones in the middle. T5 with greyish hairs with numerous black ones in the middle. T6 mostly with black hairs and some grayish ones on the sides. Coxae and femurs with black hairs intermixed with very few greyish ones. Mesotibias with black hairs some of them with red tip. Metatibias with corbiculae surrounded by decumbent bristles slightly longer that the width of the organ, mostly reddish with light blond tip and some whole black at the base of anterior margin, meso- and metabasitarsus with short reddish bristles. Distal tarsa red. Otherwise black. Labrum with a narrow labral furrow as wide as 0.23 times its total width, V-shaped. The labral tubercles are well designed. There is an imbricated microsculptures in front of the tubercles and into the labral furrow. Punctuations are very dense into the labral furrow and more spaced back to the tubercles. The front part of the labrum is covered with plumose reddish bristles. Basis of mandibulae with numerous punctuations, very dense at the base between the condyle. Clypeus slightly bombed, very covered with black plumose bristles at the distal part, and short reddish plumose ones in the middle, along the anterior edge. There is a narrow glabrous area in the middle of the anterior third. This area is covered with deep and broad punctuations. These punctuations are joining at the side of the frontal part and more spaced in the middle. There is a thin band of microsculptures along the transversal furrow at the distal part of clypeus.

Ocellar field covered with large spaced punctuations along the inner margin of the compound eyes, covering $1 / 2$ of the distance between ocelli and compound eyes. 
Between the distal margin of compound eyes, there is a poorly designed supra-orbital line only defined near the eyes.

Antennae. $\mathrm{L}(\mathrm{A} 5)=0,67 * \mathrm{~L}(\mathrm{~A} 3) ; \mathrm{L}(\mathrm{A} 4)=0,51 * \mathrm{~L}(\mathrm{~A} 3)$ (not different from B. lapponicus).

Metabasitarsus. maximal width situated apically of the diverging transversely directed hair, at 0.27 of the basitarsus length (0.19 in B. lapponicus). The glabrous area at the base of metabasitarsus with slightly imbricated micro-sculptured surface (this area is much smaller in B. lapponicus and without imbricated surface).

Males. Length 11-13 mm.

Coat color. Males are greyish and shaggy. Face and vertex largely covered by yellow hairs and a slight mixture of black and yellow hairs on vertex. Thorax with a collare as large as $1 / 3$ of the thorax length, with yellow hairs; scutellare with yellow hairs as large as 1/4 of the thorax length. The hairs of the scutellare are shaped in two oblique tufts. Pleura covered with yellow hairs; mesopleura with yellow hairs; metapleura are mostly yellow. Inter-alar band is yellow with some intermixed black hairs. In some specimens, the interalar band is attenuated with a mixture of black and yellow hairs. T1 mostly covered with yellow hairs. T2 covered with red hairs, intermixed with some yellow ones on the at the middle of anterior margin. T3 and T4 all red with few grayish hairs at the middle of posterior margin. T5 mostly covered with yellow hairs, with very few red hairs at the anterior margin and black ones in the middle. T6 with greyish hairs with numerous black ones in the middle. T7 mostly with black hairs and some grayish ones on the sides. Coxae and femurs with mostly yellow hairs intermixed with very few black ones. Mesotibias with yellow hairs some of them with reddish base with few intermixed black hairs. Metatibias with corbiculae surrounded by decumbent bristles slightly longer that the width of the organ, mostly reddish with light blond tip and some whole black at the base of anterior margin, meso- and metabasitarsus with short reddish bristles. Distal tarsa red. Otherwise black.

Labrum with a narrow labral furrow as wide as 0.21 times its total width, V-shaped. The labral tubercles are well designed. Punctuations are very dense into the labral furrow and more spaced back to the tubercles. The front part of the labrum is covered with plumose reddish bristles. Basis of mandibulae with numerous punctuations, very dense at the base between the condyle. Clypeus slightly bombed, very covered with short black bristles in the middle and longer reddish ones at the distal part. The first anterior third is covered with deep and broad punctuations. There is a thin band of microsculptures along the transversal furrow at the distal part of clypeus. 
Ocellar field covered with large spaced punctuations along the inner margin of the compound eyes, covering 1/2 of the distance between ocelli and compound eyes. Between the distal margin of compound eyes, there is a poorly designed supra-orbital line only defined near the eyes. Antennae. $\mathrm{L}(\mathrm{A} 5)=0,63 * \mathrm{~L}(\mathrm{~A} 3) ; \mathrm{L}(\mathrm{A} 4)=0,52 * \mathrm{~L}(\mathrm{~A} 3)$ (not different from B. lapponicus). Metabasitarsus. In the middle, the external side of the posterior is characterized by an area with very short black bristles (contrary to B. lapponicus with long and numerous bristles).

\section{Diagnosis}

Bombus interacti sp. nov. males differed from B. lapponicus sylvicola slightly in the pubescence of the tibia (very hairy for B. lapponicus sylvicola). No difference in the structure of the genitalia was found. For female, B. interacti sp. nov. differed from B. lapponicus sylvicola in the face coloration: black with a few intermixed yellow hairs for $B$. interacti sp. nov. and yellow with few intermixed black hairs for B. lapponicus sylvicola. The density of pubescence of tergite 5 is greater for $B$. interacti sp. nov. and the yellow coloration of collar does not extend down to the level of the front leg. Description of males and females was reported in Table 2. Holotype: One pinned male (Fig. 1C). Labels: (1) white, printed with 'USA, Alaska, Toolik field station, 725m, 28.VII.2015, 68 $37^{\circ} 32.9^{\prime \prime} \mathrm{N} 149^{\circ} 35^{\prime} 48.8^{\prime \prime} \mathrm{W}$, Epilobium angustifolium, leg. Martinet/Rasmont St88, PRAS1045; (2) red, printed with 'HOLOTYPE'; (3) white, printed with "det. Martinet \& Rasmont 2016, Bombus interacti Martinet, Brasero \& Rasmont". The left anterior leg is missing as it was removed for genetic analysis. The type has been deposited in the Royal Belgian Institute of Natural Sciences in Brussels. Genbank accession numbers: MG280603 (COI), MG280606 (PEPCK).

Paratypes: 9 males and 4 queens pinned (Fig. 1D) and labelled "Paratype".

Remarks: Considering morphology, genetic and the semio-chemical secretions, there is no available name to describe our new taxon. However, there are some uncertainties about the taxon B. gelidus (Fig. 7) described by Cresson (1878) and Franklin (1912), considered as a subspecies of B. lapponicus sylvicola by Pittioni (1943). The morphological description of Cresson (1878) is very poor and not sufficient to compare with our specimens. This description is based on one queen from Aleutian Islands (Henry Edwards). This specimen is described as black, with a long and loose pubescence; with a slight admixture on face and vertex. Sides of thorax, scutellum, and first and fourth segments of abdomen are described as pale yellow and the second and third segments mostly fulvo-ferruginous, mixed with black on middle and sides. The clypeus is sparsely punctured, labrum with fulvous hair and wings are dark and stained. In the re-description of Franklin (1912), B. gelidus is described as very closely allied to $B$. lapponicus sylvicola. However, the face of queen is mostly dark and the mesopleura is largely 
covered with yellow pile but the yellow not reaching the bases of the legs in B. gelidus. For males, coxae, trochanters and femora are characterized by a large amount of pale yellow pile. According Franklin (1912), no difference in structure between B. gelidus and $B$. lapponicus sylvicola could be found except slight differences in coloration and these taxa should be considered as conspecific. The queen holotype from the Academy of Natural Sciences (Philadelphia) and three co-types workers (from the Smithsonian National Museum of Natural History) have been examined for this study. However, for these old specimens only morphological traits are available to compare with our specimens. The morphological characters distinguishing gelidus/sylvicola/interacti females are mainly based on coat color variation. The type series is different from $B$. interacti sp. nov. based on wings coloration (gelidus has darker wing color than interacti), labrum punctuation (large punctuations in the middle and on the sides), the shape of basitarsus (sensu Gjershaug et al. 2013) (Table 2), the density of hairs on the collar for females and the pubescence of the tibia for males. The workers of the type series that we examined are not different from B. lapponicus sylvicola. There is no indication that B. gelidus would be anything other than a dark form of B. lapponicus sylvicola. However, as the type series is older (i.e. 1878), we cannot take a rational decision concerning their taxonomic assignment. In the light of our wing morphometric analysis and the lack of strong taxonomic evidence (genetic, semio-chemical) and that B. gelidus has been described only from the Aleutian Islands, we hypothesize that B. gelidus is different from B. interacti sp. nov. and we describe this latter taxon as new species. Our wing morphometric geometric analysis show that the holotype of gelidus is assigned to B. lapponicus. Even if the definitive status of B. gelidus remains unsettled, as far as we can understand now, after revision the holotype, the taxon described here as B. interacti sp. nov. is unlikely to be conspecific with gelidus. Nine males and three queens, based on chemical, genetic and morphological analyses, and seven other males based only on morphological characters, are considered to belong to interacti sp. nov. No variation in color pattern has been observed within the taxon except the density of the yellow interalar band for males in our sampling. However, our specimens have been collected from only one site (Toolik and surroundings) and the color variation could be underestimated. Its recorded host plants are Epilobium angustifolium, Senecio lugens and Solidago multiradiata. Bombus interacti sp. nov. is similar to sylvicola and was discovered using (1) analysis of a mitochondrial gene (COI) and a nuclear gene (PEPCK), (2) analysis of the cephalic labial gland secretions, (3) complete morphological examination. Type locality: Toolik field station, Alaska (USA) $\left(68^{\circ} 38^{\prime} \mathrm{N}, 149^{\circ} 36^{\prime} \mathrm{W}\right)$. 
Distribution: B. interacti sp. nov. was found higher latitudes in the arctic tundra habitat near Toolik field stations in Alaska (USA) (68 $\left.37^{\prime}-68^{\circ} 46^{\prime} \mathrm{N} 149^{\circ} 35^{\prime}-149^{\circ} 56^{\prime} \mathrm{W}\right)$. The available data are not sufficient to draw up a distribution map.

Etymology: The specific name was chosen in reference to the INTERACT project which funded most of our sampling costs allowing us to discover this taxon.

Given the slight genetic divergence obtained by COI analysis, the color pattern and the geographic distribution, we propose to assign the subspecific status to the north population of sylvicola: Bombus (Pyrobombus) lapponicus lapponicus comb. nov. in Fennoscandia and Bombus (Pyrobombus) lapponicus sylvicola comb. nov. in Alaska and Yukon.

Bombus lapponicus sylicola f. gelidus Cresson 1878 comb. nov.

Holotype. One queen pinned (Fig. 7). Labels: (1) red, printed with "HoloTYPE 2638"; (2) white, written with 'aleutian Islds Dau; (3) red, printed with "HOLOTYPE"; (4) white, printed with "Rasmont \& Martinet 2018, Bombus (Pyrobombus) lapponicus sylvicola f. gelidus Cresson, 1878". The type is conserved in the Academy of Natural Sciences in Philadelphia (USA).

B. gelidus appears as a very dark form of B. lapponicus sylvicola and should be considered as B. lapponicus sylvicola f. gelidus comb. nov.

Further material. In the Smithsonian National Museum of Natural History, Massachusetts Agricultural College and United States National Museum, there are 1 queen, 14 workers and 1 male labelled "Cotype" by Franklin (1912). All these specimens should not be part of the typical series and have been erroneously labelled. These specimens were collected later and in other areas than the only holotype described by Cresson (1878). After examination, we consider that these specimens as typical color form of B. lapponicus sylvicola.

\section{Discussion}

Taxonomic status of B. lapponicus sylvicola f. gelidus comb. nov. , B. interacti sp. nov., $B$. lapponicus and B. lapponicus sylvicola comb. nov.

The phylogenetic trees performed by Hines et al. (2006) and Cameron et al. (2007) show low bootstrap values between B. lapponicus lapponicus and B. lapponicus sylvicola while the two taxa displayed some genetic divergences in $\operatorname{ArgK}, 16 \mathrm{~S}$ and Ef-1 $\alpha$. However, the only specimen of sylvicola used in Cameron et al. (2007) and Hines et al. (2006) had been collected in New Mexico (USA) where the taxon displays a particular color form with tergite 2 and 3 predominantly black (T2-3 red in Alaska), although these two forms of B. lapponicus sylvicola are considered as conspecific (Williams et al. 2015). Without a complete taxonomic revision, 
we cannot exclude that northern and southern populations are two different lineages considering the taxonomic ambiguities present in this group. Koch et al. (2017), showed that in its distribution, sylvicola display different allelic diversity and they emphasize different genetic cluster (population genetic structure differentiation). As suggested in Cameron et al. (2007), the PEPCK gene fragment showed no differentiation between B. lapponicus lapponicus and the north population of B. lapponicus sylvicola while COI fragment showed a low divergence (Fig. 2). This could reflect a geographic intraspecific variability (Andriollo et al. 2015; Mutanen et al. 2016) between two isolated and geographically distant populations. Genetic results are in line with CLGS analyses which support a lack of divergence between B. lapponicus lapponicus and B. lapponicus sylvicola (intra-specific variability) and suggest that these taxa are conspecific according to the species recognition concept (Paterson 1993) (Fig. 3B) and our taxonomic integrative approach (Table 3). There could be no chemical reproductive barrier (Ayasse \& Jarau 2014) between B. lapponicus from Scandinavia, W-Siberia and B. sylvicola from Alaska and Yukon. However, the reinforcement of reproductive barriers process could not be exerted on the CLGS between allopatric species. Overall, as there is no divergence in nuclear gene, in morphology (structure of the genitalia) and in CLGS, we can expect that there is no reproductive barrier between the populations. Poor quantitative differences observed could just reflect a "dialect divergence" due to the geographical gap between these two sampled populations (Lecocq et al. 2013b) or chemical background noise.

Moreover, our integrative framework (Table 3) highlights an unknown species from Alaska in the lapponicus-group supported by all our independent criteria: B. interacti sp. nov. (Table 3). Morphological, genetic and semio-chemical datasets support the presence of two biologically distinct taxa within sylvicola sampling from Alaska. CLGS results strongly support also the new species $B$. interacti sp. nov. with different major and indicator compounds from monticola, konradini, lapponicus lapponicus and lapponicus sylvicola. Although we have a restricted sampling and different tree topologies between the two genetic markers, nuclear gene analysis suggests that $B$. interacti sp. nov. is closer to $B$. monticola (also consistent with the morphology, see Table 2), a strictly European taxon. This could question the distribution of their potential common ancestor around the Arctic Circle. One hypothesis could be that the speciation of $B$. interacti sp. nov. occurred from successive waves of range expansion and contraction following glaciations and the dynamic of Bering Strait (Abbott and Brochmann 2003; Elias and Brigham-Grette 2013; Pringle 2014). In the case of our new species B. interacti, we emphasize that we have especially strong and straightforward evidence of the differentiation 
592

593

594

595

596

597

598

599

600

601

602

603

604

605

606

607

608

609

610

611

612

613

614

615

616

617

of this taxon given that all data support this divergence. Further inter-population genetic analyses are needed to explore this hypothesis.

For the taxon gelidus, considering morphological criteria and wing geometric morphometric analyses (Fig. 6), we propose to consider this taxon as a "dark" form of $B$. lapponicus sylvicola: B. lapponicus sylvicola $\mathrm{f}$. gelidus comb. nov.

Bombus lapponicus: a circum polar taxon

Based on morphological characters and the coat coloration, Skorikov (1922) and Pittioni (1942) had already hypothesized that there is a set of conspecific taxa related to B. lapponicuscomplex all around the Arctic Circle (i.e. B. lapponicus zaitzevi Skorikov, 1913 in the northern Urals; B. lapponicus karaginus Skorikov,1912 from Chukotka; B. glacialis Friese, 1902 from Novaya Zemlya, and Wrangel Island). However, most taxa of this B. lapponicus-complex have never been investigated by genetic or chemical data. Formerly, only the Scandinavian population of the lapponicus group was sampled by Svensson \& Bergström (1977) to study the cephalic labial gland secretions. Our results based on the sampling of five distant populations (North Sweden, West Siberia, North Alaska, Yukon and North Quebec for wing shape analysis) seem therefore to confirm the hypothesis of Skorikov (1922) and Pittioni (1942) presenting $B$. lapponicus sensu stricto as a northern Holarctic species, with different isolated allopatric subspecies in the polar portion of its distribution. Moreover, Potapov et al. (2017) have shown the conspecificity of specimens of lapponicus from Norway, Kamchatka, Yamal and Chukotka based on COI analysis. These results confirm our hypothesis: B. lapponicus is found across northern Holarctic regions, including a circumpolar distribution and exhibit subspecific differentiation across at least the polar section of its distribution. The absence of differentiation in CLGS and genetic analyses across the Holarctic region suggest that there is no isolation mechanism between any lapponicus populations. These taxa do not seem to be involved in an Artenkreis speciation process sensu Rensch 1933. 


\section{References}

Abbott RJ, Brochmann C. 2003. History and evolution of the arctic flora: in the footsteps of Eric Hultén. Moleular Ecolology 12: 299-313.

Adams DC \& Otárola-Castillo E. 2013. Geomorph: An R package for the collection and analysis of geometric morphometric shape data. Methods in Ecology and Evolution 4(4): 393-399.

Alcaide M, Scordato ESC, Price TD, Irwin DE. 2014. Genomic divergence in a ring species complex. Nature 51: 83-85.

Alström P. 2006. Species concepts and their application: Insights from the genera Seicercus and Phylloscopus. Acta Zoologica Sinica 52: 429-434.

Andriollo T, Naciri Y, Ruedi M. 2015. Two mitochondrial barcodes for one biological species: the case of European Kuhl's Pipistrelles Chiroptera. PlosOne 10: e0134881.

Ayasse M, Jarau S. 2014. Chemical ecology of bumble bees. Annual Review of Entomology 59: $299-319$.

Baer B. 2003. Bumblebees as model organisms to study male sexual selection in social insects. Behavioral Ecology and Sociobiology 54: 521-533.

Batalha-Filho H, Waldschmidt A, Campos LAO, Tavares MG, Fernandes-Salomao T. 2010. Phylogeography and historical demography of the Neotropical stingless bee Melipona quadrifasciata (Hymenoptera, Apidae): incongruence between morphology and mitochondrial DNA. Apidologie 41: 534-547.

Bertsch A, Schweer H. 2012. Cephalic labial gland secretions of males as species recognition signals in bumblebees: are there really geographical variations in the secretions of the Bombus terrestris subspecies? Beiträge zur Entomologie 62: 103-124.

Bickford D, Lohman DJ, Sodhi NS, Ng PKL, Meier R, Winker K, Ingram KK, Das I. 2007. Cryptic species as a window on diversity and conservation. Trends in Ecology and Evolution 22: 148-155.

Biella P, Bogliani G, Cornalba M, Manino A, Neumayer J, Porporato M, Rasmont P, Milanesi P. 2017. Distribution patterns of the cold adapted bumblebee Bombus alpinus in the Alps and hints of an uphill shift (Insecta: Hymenoptera: Apidae). Journal of Insect Conservation $21: 357$.

Bookstein FL. 1991. Morphometric tools for landmark data: geometry and biology. Cambridge University Press, Cambridge, 435 p. 
Botero CA, Dor R, McCain CM, Safran RJ. 2014. Environmental harshness is positively correlated with intraspecific divergence in mammals and birds Molecular Ecology 23: 259-268.

Brown JH. 2014. Why are there so many species in the tropics? Journal of Biogeography 41 (1): 8-22.

Calam, DH. 1969. Species and sex-specific compounds from the heads of male bumblebees (Bombus spp). Nature 221: 856-857.

Cameron SA, Hines HM, Williams PH. 2007. A comprehensive phylogeny of the bumble bees (Bombus). Biological Journal of the Linnean Society 91: 161-188.

\section{Carolan JC, Murray TE, Fitzpatrick U, Crossley J, Schmidt H, Cederberg B, McNally L,} Paxton RJ, Williams PH, Brown MJF. 2012. Colour patterns do not diagnose species: quantitative evaluation of a DNA barcoded cryptic bumblebee complex. PLOS ONE 7: e29251.

Chapin FS, Körner C. 1995. Arctic and Alpine Biodiversity: Patterns, Causes and Ecosystem consequences. Ecological studies 113, Berlin Heidelberg, p.336.

Claudet J, Pelletier D, Jouvenel JY, Bachet F, Galzin R. 2006. Assessing the effects of Marine Protected Area (MPA) on a reef fish assemblage in a northwestern Mediterranean marine reserve: identifying community-based indicators. Biological Conservation 130: 346-369.

Coppée A, Terzo M, Valterova I, Rasmont P. 2008. Intraspecific variation of the cephalic labial gland secretions in Bombus terrestris (L.) (Hymenoptera: Apidae). Chemistry \& Biodiversity 5: 2654-2661.

Cresson ET.1878. Descriptions of new species of North American bees. Proceedings of the Academy of natural Sciences of Philadelphia 1878: 181-221.

Dellicour S, Lecocq T. 2013a. GCALIGNER 1.0 and GCKOVATS 1.0 - Manual of a Software Suite to Compute a Multiple Sample Comparison Data Matrix from Eco-chemical Datasets Obtained by Gas Chromatography. University of Mons, Mons.

Dellicour S, Lecocq T. 2013b. GCALIGNER 1.0: an alignment program to compute a multiple sample comparison data matrix from large eco-chemical datasets obtained by GC. Journal of Separation Science 36: 3206-3209.

De Meulemeester T, Gerbaux P, Boulvin M, Coppee A, Rasmont P. 2011. A simplified protocol for bumble bee species identification by cephalic secretion analysis. Insectes Sociaux 58: 227-236. 
De Queiroz K. 2007. Species concepts and species delimitation. Systematic Biology 56: 879886.

Drummond AJ \& Rambaut A. 2007. BEAST: bayesian evolutionary analysis bysampling trees. BMC Evolutionary Biology 7: 214.

Dufrene M, Legendre P. 1997. Species assemblages and indicator species: The need for a flexible asymmetrical approach. Ecological Monographs 67: 345-366.

Elias SA \& Brigham-Grette J. 2013. Glaciations - Late Pleistocene Glacial Events in Beringia, in: Encyclopedia of Quaternary Science (Second Edition), Elsevier, Amsterdam.

Engel MS. 2011. Systematic melittology: where to from here? Systematic Entomology 36: 215.

Ennen JR, Kalis ME, Patterson AL, Kreiser BR, Lovich JE, Godwin J, Qualls CP. 2014. Clinal variation or validation of a subspecies? A case study of the Graptemys nigrinoda complex (Testudines: Emydidae). Biological Journal of the Linnean Society 111: 810-822.

Estoup A, Solignac M, Cornuet JM, Goudet JS. 1996. Genetic differentiation of continental and island populations of Bombus terrestris (Hymenoptera: Apidae) in Europe. Molecular Ecology 5: 19-31.

Franklin HJ. 1912. The Bombidae of the New World. Transactions of the American Entomological Society 38 (3/4): 177-486.

Gjershaug J, Staverløkk A, Kleven O, Ødegaard F. 2013. Species status of Bombus monticola Smith (Hymenoptera: Apidae) supported by DNA barcoding. Zootaxa 3716: 431-440.

Hawlitschek O, Nagy ZT, Glaw F. 2012. Island evolution and systematic revision of Comoran snakes: why and when subspecies still make sense. PLOS ONE 7: e42970.

Hillis DM, Bull JJ. 1993. An empirical test of bootstrapping as a method for assessing confidence in phylogenetic analysis. Systematic Biology 42: 182-192.

Hines HM, Camero SA, Williams PH. 2006. Molecular phylogeny of the bumble bee subgenus Pyrobombus (Hymenoptera: Apidae: Bombus) with insights into gene utility for lower-level analysis. Invertebrate Systematics 20: 289-303.

Huberty CJ \& Olejnik S. 2006. Applied MANOVA and discriminant analysis. Second Edition. New Jersey, 488 p. 
Ings TC, Ings NL, Chittka L, Rasmont P. 2010. A failed invasion? Commercially introduced pollinators in Southern France. Apidologie 41: 1-13.

Irwin DE, Irwin HJ, Price TD. 2001a. Ring species as bridges between microevolution and speciation. Genetica 112/113: 223-243.

Irwin DE, Bensch S, Price TD. 2001b. Speciation in a ring. Nature 409: 333-337.

Irwin DE, Bensch S, Irwin JH, Price TD. 2005. Speciation by distance in a ring species. Science 307: 414-416.

Kevan PG. 1973. Flowers, insects, and pollination ecology in the Canadian high Arctic. Polar Record 16: 667-674.

Koch JB, Looney C, Sheppart WS, Strange JP. 2017. Patterns of population genetic structure and diversity across bumble bee communities in the Pacific Northwest. Conservation Genetics 18 (3): 507-520.

Leaché AD, Fujita MK. 2011. Bayesian species delimitation in West African forest geckos (Hemidactylus fasciatus). Proceeding of the Royal Society B 278: 493-495.

Lecocq T, Lhomme P, Michez D, Dellicour S, Valterova I, Rasmont P. 2011. Molecular and chemical characters to evaluate species status of two cuckoo bumblebees: Bombus barbutellus and Bombus maxillosus (Hymenoptera, Apidae, Bombini). Systematic Entomology 36: 453-469.

Lecocq T, Dellicour S, Michez D, Lhomme P, Vanderplanck M, Valterova I, Rasplus JY, Rasmont P. 2013a. Scent of a break-up: phylogeography and reproductive trait divergences in the red-tailed bumblebee (Bombus lapidarius). BMC Evolutionary Biology 13: 263.

Lecocq T, Vereecken NJ, Michez D, Dellicour S, Lhomme P, Valterova I, Rasplus JY, Rasmont P. 2013b. Patterns of genetic and reproductive traits differentiation in mainland vs. Corsican populations of bumblebees. PLoS ONE 8: e65642.

Lecocq T, Brasero N, De Meulemeester T, Michez D, Dellicour S, Lhomme P, De Jonghe R, Valterova I, Urbanova K, Rasmont P. 2015a. An integrative taxonomic approach to assess the status of Corsican bumblebees: implications for conservation. Animal Conservation 18: 236-248.

Lecocq T, Coppee A, Mathy T, Lhomme P, Cammaerts-Tricot MC, Urbanova K, Valterova I, Rasmont P. 2015b. Subspecific differentiation in male reproductive traits and virgin queen preferences, in Bombus terrestris. Apidologie 46 (5): 595 605. 
Lecocq T, Dellicour S, Michez D, Dehon M, Dewulf A, De Meulemeester T, Brasero N, Valterova I, Rasplus JY, Rasmont P. 2015c. Methods for species delimitation in bumblebees (Hymenoptera, Apidae, Bombus): towards an integrative approach. Zoologica Scripta 44: 281-297.

Lecocq T, Coppée A, Michez D, Brasero N, Rasplus JY, Valterová I, \& Rasmont P. 2016. The alien's taxonomic identity: consequences of taxonomic status for the international bumble bee trade regulation. Biological Conservation 195 : 169-176.

Løken A. 1973. Studies on Scandinavian bumble bees Hymenoptera, Apidae. Norsk Entomologisk Tidsskrift 20: 1-218.

Lomolino MV, Riddle BR, Whittaker RJ, Brown JH. 2010. Biogeography, 4th edn. Sinauer, Sunderland MA.

Martinet B, Lecocq T, Brasero N, Biella P, Urbanová K, Valterová I, Cornalba M, Gjershaug JO, Michez D, Rasmont P. 2017. Following the Cold: Geographic Differentiation between Interglacial Refugia and Speciation in Arcto-Alpine Species Complex Bombus monticola (Hymenoptera: Apidae). Systematic Entomology, doi 10.1111/syen.12268.

Mayr E. 1942. Systematics and the Origin of Species. Columbia University Press, New York, New York.

Mayr E. 1963. Animal Species and Evolution. Harvard University Press, Cambridge, Massachusetts.

Michener CD. 2007. The Bees of the World. Second Edition. Johns Hopkins University, Baltimore, $1016 \mathrm{p}$.

Monahan WB, Pereira RJ, Wake DB. 2012. Ring distributions leading to species formation: a global topographic analysis of geographic barriers associated with ring species. BMC Biology 10: 20.

Mutanen M, Kivelä SM, Vos RA, Doorenweerd C, Ratnasingham S, Hausmann A, Huemer P, Dincă V, van Nieukerken EJ, Lopez-Vaamonde C, Vila R, Aarvik L, Decaëns T, Efetov KA, Hebert PD, Johnsen A, Karsholt O, Pentinsaari M, Rougerie R, Segerer A, Tarmann G, Zahiri R, Godfray HC. 2016. SpeciesLevel Para- and Polyphyly in DNA Barcode Gene Trees: Strong Operational Bias in European Lepidoptera. Systematic Biology 65: 1025-1040. 
Oksanen FJ, Blanchet G, Kindt R, Legendre P, McGlinn D, Minchin PR, O'Hara RB, Simpson GL, Solymos P, Stevens MHH, Szoecs E, Wagner H. 2011. Tertiary Vegan: Community Ecology Package.

Päckert M, Martens J, Eck S, Nazarenko AA, Valchuk OP, Petri B, Veith M. 2005. The great tit (Parus major) - A misclassified ring species. Biological Journal of the Linnean Society 86: 153-174.

Padial JM, Miralles A, De la Riva I \& Vences M. 2010. The integrative future of taxonomy. Frontiers in zoology 7: 16.

Paradis E, Claude J, Strimmer K. 2004. APE: analyses of phylogenetics and evolution in R language. Bioinformatics 20: 289-290.

Patten MA, Pruett CL. 2009. The Song Sparrow, Melospiza melodia, as a ring species: patterns of geographic variation, a revision of subspecies, and implications for speciation. Systematics and Biodiversity 7 (1): 33-62.

Paterson HEH. 1993. Evolution and the Recognition Concept of Species. The Johns Hopkins University Press, Baltimore, Maryland.

Pedersen BV. 2002. European bumblebees Hymenoptera: Bombini - Phylogenetic relationships inferred from DNA sequences. Insect Systematics and Evolution, 33:361-386.

Pekkarinen A. 1982. Morphology and specific status of Bombus lapponicus Fabricius and B. monticola Smith Hymenoptera: Apidae. Entomologica Scandinavia 13: 41-46.

Pekkarinen A, Teräs I, Viramo J, Paatela J. 1981. Distribution of bumblebees (Hymenoptera, Apidae: Bombus and Psithyrus) in eastern Fennoscandia. Notulae Entomologicae 61: 71-89.

Pittioni B. 1942. Die boreoalpinen Hummeln und Schmarotzerhummeln (Hymen., Apidae, Bombinae). I. Teil. Mitteilungen aus den Köninglichen Naturwissenschaftlicàen Instititen in Sofia 15: 155-218.

Pittioni B. 1943. Die boreoalpinen Hummeln und Schmarotzerhummeln (Hymen., Apidae, Bombinae). II. Teil. Mitteilungen aus den Köninglichen Naturwissenschaftlicàen Instititen in Sofia 16: 1-77.

Posada D. 2008. jModelTest: Phylogenetic model averaging. Molecular Biology and Evolution 25: $1253-1256$. 
Potapov GS, Kondakov AV, Spitsyn VM, Filippov B YU, Kolosova Yu S, Zubrii NA, Bolotov IN. 2017. An integrative taxonomic approach confirms the valid status of Bombus glacialis, an endemic bumblebee species of the High Arctic. Polar Biology 41: 629-642.

Pringle H. 2014. Welcome to Beringia. Science 343: 961-963.

Proshchalykin MY, Kupianskaya AN. 2005. The bees (Hymeoptera, Apoidea) of the Northern part of the Russian far east. Far Eastern Entomologist 153:1-39.

Rasmont P, Terzo M, Aytekin AM, Hines H, Urbanova K, Cahlikova L, Valterova I. 2005. Cephalic secretions of the bumblebee subgenus Sibiricobombus Vogt suggest Bombus niveatus Kriechbaumer and Bombus vorticosus Gerstaecker are conspecific (Hymenoptera, Apidae, Bombus). Apidologie 36: 571-584.

R Development Core Team. 2016. R: A Language and Environment for Statistical Computing. R Foundation for Statistical Computing, Vienna. [WWW document]. URL http://www.R-project.org/ [accessed on 17 October 2017].

Reid NM. \& Carstens BC. 2012. Phylogenetic estimation error can decrease the accuracy of species delimitation: a Bayesian implementation of the general mixed Yulecoalescent model. BMC Evolutionary Biology 12: 196.

Reinig WF. 1937. Die Holarktis. Ein Beitrag zur diluvialen und alluvialen Geschichte der Cirkumpolaren Faunen- und Florengebiete. Gustav Fischer, Jena, 124 p.

Rensch B. 1933. Zoologische Systematik und Artbildungsprobleme. Verhandlungen der Dtsch. Zool. Geselschaft Zoologischer Anzeiger 6: 19-83.

Rohlf FJ. 1999. Shape statistics: Procrustes superimpositions and tangent spaces. Journal of Classification 16: 197-223.

Rohlf FJ. 2013a. tpsSMALL Version 1.25. Department of Ecology and Evolution, State University of New York at Stony Brook, New-York.

Rohlf FJ. 2013b. tpsUTIL Version 1.56. Department of Ecology and Evolution, State University of New York at Stony Brook, New-York.

Rohlf FJ. 2013c. tpsDIG Version 2.17. Department of Ecology and Evolution, State University of New York at Stony Brook, New-York.

Rohlf FJ \& Slice D. 1990. Extensions of the Procrustes method for the optimal superimposition of landmarks. Systematic Zoology 39: 40-59.

Ronquist F, Huelsenbeck JP. 2003. MrBayes 3: bayesian phylogenetic inference under mixed models. Bioinformatics 19: 1572-1574. 
Savard M. 2009. Aperçu sur la diversité des bourdons de la Minganie, Québec (Hymenoptera : Apidæ : Bombus). Le Naturaliste canadien 133 (2): 31-36.

\section{Schlick-Steiner BC, Steiner FM, Seifert B, Stauffer C, Christian E, Crozier R.H. 2010.} Integrative taxonomy: a multisource approach to exploring biodiversity. Annual Review of Entomology 55: 421-438.

Shamurin VF. 1966. Rol' nasekomikh-opilitelei v tundrovikh soobshchestvakh. [The role of insects in tundra communities]. Organizmi iprirodnayasreda. Voprosi geographii 69: 98-117 (in Russian).

Sladen FWL. 1919. The wasps and bees collected by the Canadian Arctic Expedition, 191318. In: Report of the Canadian Arctic Expedition, 1913-18. Insects 3: 25G-35G.

Skorikov AS. 1922. Shmeli paleartiki. Chast I. Obshchaya biologia (so vklyucheniem zoogeografi i). [Les bourdons de la faune palearctique. Partie 1. Biologie générale (la zoogéographie y compris)]. Izvestiya Severnoi Oblastnoi Stantsii Zashchity Rastenii ot Vreditelei 4: 1-160.

Skorikov AS. 1937. Die grönländischen Hummeln im Aspekte der Zirkumpolarfauna. Entomologiske Meddelelser 20: 37-64.

Stresemann E, Timofeeff-Ressovsky NW. 1947. Artentstehung in geographischen Formenkreisen. I. Der Formenkreis Larus argentatus-cachinnans-fucus. Biologisches Zentralblatt 66: 57-76.

Suzuki R, Shimodaira H. 2011. Pvclust: Hierarchical Clustering with P-values via Multiscale Bootstrap Resampling. Contributed package. Version 1-1.10. R Foundation for Statistical Computing, Vienna. [WWW document]. URL http://www.R-project.org [accessed on 17 October 2017].

Svensson BG. 1980. Species-isolating mechanisms in male bumblebees (Hymenoptera, Apidae). Acta Universitatis Upsaliensis 549: 1-42.

Svensson BG, Bergström G. 1977. Volatile marking secretions from the labial gland of north European Pyrobombus D. T. males (Hymenoptera, Apidae). Insectes Sociaux 24: 213-224.

Terzo M, Urbanova K, Valterova I. Rasmont P. 2005. Intra and interspecific variability of the cephalic labial glands' secretions in male bumblebees: the case of Bombus (Thoracobombus) ruderarius and B. (Thoracobombus) sylvarum Hymenoptera, Apidae. Apidologie 36: 85-96. 
Thorp RW. 1962. Notes on the distributions of some bumblebees of western North America (Hymenoptera: Apidae). Pan-Pacific Entomologist 38: 21-28.

Thorp RW, Horning DS, Dunning LL. 1983. Bumble bees and Cuckoo Bumble bees of California (Hymenoptera: Apidae. Bulletin of the California insect Survey 23: viii $+79 \mathrm{p}$.

Wilcox TP, Zwickl DJ, Heath TA, Hillis DM. 2002. Phylogenetic relationships of the dwarf boas and a comparison of Bayesian and bootstrap measures of phylogenetic support. Molecular Phylogenetics and Evolution 25: 361-371.

Williams PH. 1998. An annotated checklist of bumble bees with an analysis of patterns of description (Hymenoptera: Apidae, Bombini). Bulletin of the Natural History Museum (Entomology) 67: 79-152.

Williams PH, Brown MJF, Carolan JC, An J, Goulson D, Aytekin AM, Best LR, Byvaltsev AM, Cederberg B, Dawson R, Huang J, Ito M, Monfared A, Raina RH, Schmid-Hempel P, Sheffield CS, Sima P, Xie Z. 2012. Unveiling cryptic species of the bumblebee subgenus Bombus s. str. worldwide with COI barcodes (Hymenoptera: Apidae). Systematics and Biodiversity 10(1): 21-56.

Williams PH, Thorp R, Richardson L, Colla S. 2014. Bumble Bees of North America. New Jersey: Princeton University Press, 208 p.

Williams PH, Byvaltsev AM, Cederberg B, Berezin MV, Ødegaard F, Rasmussen C, Richardson LL, Huang J, Sheffield CS, Williams ST. 2015. Genes suggest ancestral colour polymorphisms are shared across morphologically cryptic species in arctic bumblebees. PLOS One 10(2): e0144544.

Willig MR, Kaufman DM, Stevens RD. 2003. Latitudinal gradients of biodiversity: pattern, process, scale, and synthesis. Annual Review of Ecology, Evolution, and Systematics 34: 273-309.

Žacek P, Prchalova-Hornakova D, Tykva R, Kindl J, Vogel H, Svatoš A, Pichová I, Valterová I. 2013. De novo biosynthesis of sexual pheromone in the labial gland of bumblebee males. ChemBioChem 14: 361-371.

Zwickl DJ. 2006. Genetic algorithm approaches for the phylogenetic analysis of large biological sequence datasets under the maximum likelihood criteria. $\mathrm{PhD}$ Dissertation, The University of Texas, Austin, Texas. 
Figure 1. Photos of three studied bumblebees: A. Bombus lapponicus male, B. B. sylvicola male, C. B. interacti sp. nov. male (holotype), D. B. interacti sp. nov. female (paratype) (Photos P. Rasmont).

Figure 2. A) Majority rule (50\%) consensus tree based on maximum likelihood analyses of nuclear PEPCK marker. B) Majority rule (50\%) consensus tree based on maximum likelihood analyses of mitochondrial COI marker Values above branches are maximum likelihood bootstrap values/Bayesian posterior probabilities.

Figure 3. Species recognition pairwise matrix. Species recognition pairwise matrix based on ultrametric tree of cytochrome oxidase 1 (COI) sequences with bGMYC pairwise probability of conspecificity plotted on a sample tree from BEAST. The colored matrix corresponds to the pairwise probabilities of conspecificity returned by the bGMYC method (color scale on the right of the figure). Black spots show the coalescent node for each species. The larger bees represent the typical color patterns of queens.

Figure 4. A) Dendrogram based on cephalic labial gland secretions within Bombus lapponicus + B. sylvicola (light blue), B. monticola (green), B. bimaculatus (black), B. interacti sp. nov. (red), B. terrestris (pink), B. ephippiatus (dark blue) and B. konradini (orange). This cluster was obtained by hierarchical clustering using an unweighted pair-group method with arithmetic mean (UPGMA) based on a Canberra matrix calculated from the cephalic labial gland secretion matrix. The values near nodes represent multiscale bootstrap resampling values. B) Principal component analysis (PCA) of cephalic labial gland secretion differentiation within lapponicussylvicola complex: Bombus lapponicus + B. sylvicola (light blue), B. monticola (green), B. bimaculatus (black), B. interacti sp. nov. (red), B. terrestris (pink), B. ephippiatus (dark blue) and B. konradini (orange). PC1 and PC2 are the first and second principal component axes.

Figure 5. Ordination of wing morphometry of Bombus lapponicus lapponicus, B. lapponicus sylvicola, B. lapponicus sylvicola f. gelidus and B. interacti sp. nov. along the first two axes of the principal component analysis. The two first axes of the PCA explain $28 \%$ of the total variance. Group means are represented by different symbols: red triangle for $B$. interacti sp. nov. queens; a light blue cross for B. lapponicus lapponicus and B. lapponicus sylvicola and a dark blue rectangle for B. lapponicus sylvicola $\mathrm{f}$. gelidus.

Figure 6. Photos of the different morphological diagnostic characters between sylvicola and interacti sp. nov.: A. Face of B. interacti female BMAR0892, B. Face of sylvicola female BMAR0900, C. Right profile of B. interacti female BMAR0892 with the yellow coloration of collar that does not go down until leg insertion, D. Right profile of B. sylvicola female BMAR0900 with the yellow coloration of collar that goes down until leg insertion, E. Posterior 
942 legs of B. interacti male with hairy tibia PRAS1045, F. Posterior legs of sylvicola male BMAR

943 0141with very hairy tibia, G. Genitalia of $B$. interacti male PRAS1045, H. Genitalia of $B$. 944 sylvicola male BMAR 0141 (Photos P. Rasmont).

945 Figure 7. Pictures of the holotype B. lapponicus sylvicola f. gelidus (female): A. head of $B$. 946 lapponicus sylvicola $\mathrm{f}$. gelidus female, right habitus of B. lapponicus sylvicola f. gelidus female 947 (Photos P. Rasmont).

948 Figure S1. Circum arctic sampling map (Azimuthal equidistant projection, after Uwe Dedering, 949 licensed under the Creative Commons Attribution-Share Alike 3.0 Unported license) on which 950 the red dots indicate the areas where we collected specimens of Bombus lapponicus lapponicus, 951 B. lapponicus sylvicola and B. interacti sp. nov., the red square indicates the locus typicus of $B$. 952 lapponicus sylvicola f. gelidus.

953 Figure S2. Right forewing of Bombus lapponicus sylvicola with the 18 landmarks indicated to 954 describe the shape. 
956 Table 1. List of main compounds identified for Bombus lapponicus, B. sylvicola, B. monticola,

957 B. interacti sp. nov., B. konradini, B. bimaculatus, B. ephippiatus, and B. terrestris within

958 cephalic labial gland secretions. $M W=$ the molecular weight, $M=$ median of relative

959 concentration of compound $(\%), \mathrm{n}=$ number of specimens analyzed. Complete information is

960 available in Appendix S2.

961

\begin{tabular}{|c|c|c|c|c|c|c|c|c|c|}
\hline Compounds & MW & $\begin{array}{c}\text { B. monticola } \\
(\mathrm{n}=9)\end{array}$ & $\begin{array}{c}\text { B. sylvicola } \\
(\mathrm{n}=14)\end{array}$ & $\begin{array}{l}\text { B. lapponicus } \\
(\mathrm{n}=\mathbf{2 0})\end{array}$ & $\begin{array}{c}\text { B. interacti sp. } \\
\text { nov. }(\mathrm{n}=9)\end{array}$ & $\begin{array}{c}\text { B. konradini } \\
(n=2)\end{array}$ & $\begin{array}{c}\text { B. bimaculatus } \\
(\mathrm{n}=10)\end{array}$ & $\begin{array}{c}\text { B. terrestris } \\
\quad(n=6)\end{array}$ & $\begin{array}{c}\text { B. ephippiatus } \\
(n=3)\end{array}$ \\
\hline & & M & M & M & M & M & M & M & M \\
\hline Dihydrofarnesol & 224 & $0.00 \%$ & $0.00 \%$ & $0.00 \%$ & $0.00 \%$ & $0.00 \%$ & $0.00 \%$ & $31.72 \%$ & $0.00 \%$ \\
\hline Hexadecanoic acid & 256 & $0.95 \%$ & $1.45 \%$ & $0.30 \%$ & $0.00 \%$ & $0.00 \%$ & $0.00 \%$ & $0.00 \%$ & $22.06 \%$ \\
\hline Hexadec-9-enyl acetate & 282 & $52.60 \%$ & $0.23 \%$ & $0.08 \%$ & $0.15 \%$ & $51.53 \%$ & $34.67 \%$ & $0.00 \%$ & $0.20 \%$ \\
\hline Geranyl citronellol & 292 & $0.00 \%$ & $64.00 \%$ & $71.15 \%$ & $0.00 \%$ & $0.00 \%$ & $0.00 \%$ & $0.00 \%$ & $0.00 \%$ \\
\hline Ethyl octadec-9-enoate & 310 & $0.46 \%$ & $0.00 \%$ & $0.00 \%$ & $1.80 \%$ & $8.28 \%$ & $0.00 \%$ & $0.00 \%$ & $1.44 \%$ \\
\hline Citronellyl hexadec-9-enoate & 332 & $0.00 \%$ & $0.00 \%$ & $0.00 \%$ & $15.18 \%$ & $0.00 \%$ & $0.00 \%$ & $0.00 \%$ & $0.00 \%$ \\
\hline Geranyl geranyl acetate & 392 & $0.00 \%$ & $0.00 \%$ & $0.00 \%$ & $0.00 \%$ & $0.00 \%$ & $31.22 \%$ & $0.00 \%$ & $0.00 \%$ \\
\hline
\end{tabular}

962

963 
Table 2. Main morphological and color pattern differences (male and female) between $B$.

(1912), Løken (1973), Williams (2014) and personal observations.

\begin{tabular}{|c|c|c|c|c|c|c|}
\hline & interacti sp. nov. & $\begin{array}{l}\text { lapponicus } \\
\text { sylvicola }\end{array}$ & $\begin{array}{l}\text { lapponicus } \\
\text { lapponicus }\end{array}$ & $\begin{array}{l}\text { monticola } \\
\text { scandinavicus }\end{array}$ & konradini & $\begin{array}{l}\text { lapponicus } \\
\text { sylvicolaf. } \\
\text { gelidus comb. } \\
\text { nov. }\end{array}$ \\
\hline Range & North Alaska & $\begin{array}{l}\text { Widespread in most } \\
\text { northern North } \\
\text { America and in } \\
\text { Californian } \\
\text { mountains }\end{array}$ & $\begin{array}{l}\text { Fennoscandia, N. } \\
\text { Russia }\end{array}$ & Fennoscandia & $\begin{array}{l}\text { Central } \\
\text { Apennines }\end{array}$ & $\begin{array}{l}\text { Aleutian } \\
\text { Islands }\end{array}$ \\
\hline \multicolumn{7}{|l|}{ Female } \\
\hline \multicolumn{7}{|l|}{ Morphology } \\
\hline $\begin{array}{l}\text { Coat color } \\
\text { variation }\end{array}$ & $\begin{array}{l}\text { Light and } \\
\text { colorful }\end{array}$ & Light and colorful & $\begin{array}{l}\text { Varies from very } \\
\text { light and colorful } \\
\text { in Northern } \\
\text { Fennoscandia, to } \\
\text { rather dark in } \\
\text { Southern } \\
\text { Fennoscandia } \\
\text { (Southern } \\
\text { Norway) }\end{array}$ & Dark & Large and light & Dark \\
\hline Body size & $15-18 \mathrm{~mm}$ & $15-17 \mathrm{~mm}$ & $15-19 \mathrm{~mm}$ & $14-19 \mathrm{~mm}$ & $15-18 \mathrm{~mm}$ & $16-18 \mathrm{~mm}$ \\
\hline \multicolumn{7}{|l|}{ Color pattern } \\
\hline Face & $\begin{array}{l}\text { Black with few } \\
\text { yellow hairs }\end{array}$ & Yellow & $\begin{array}{l}\text { Black with few } \\
\text { yellow hairs }\end{array}$ & Black & Yellow & $\begin{array}{l}\text { Black with few } \\
\text { yellow hairs }\end{array}$ \\
\hline $\begin{array}{l}\text { Collar and } \\
\text { scutellar }\end{array}$ & $\begin{array}{l}\text { Yellow but collar } \\
\text { does not go down } \\
\text { until leg insertion }\end{array}$ & $\begin{array}{l}\text { Large and yellow } \\
\text { goes down until leg } \\
\text { insertion }\end{array}$ & $\begin{array}{l}\text { Yellow but less } \\
\text { wide, the } \\
\text { coloration stops at } \\
\text { the tegulae }\end{array}$ & Small dark yellow & $\begin{array}{l}\text { Wide yellow } \\
\text { band to the } \\
\text { tegulae/ yellow }\end{array}$ & $\begin{array}{l}\text { Yellow but } \\
\text { collar does not } \\
\text { go down until } \\
\text { leg insertion }\end{array}$ \\
\hline $\begin{array}{l}\text { Hind meta- } \\
\text { basitarsus }\end{array}$ & $\begin{array}{l}\text { Slight } \\
\text { pubescence and } \\
\text { the maximal } \\
\text { width of the } \\
\text { basitarsus is high } \\
\text { as B. monticola } \\
\text { (sensu Gjershaug } \\
\text { et al., 2013). }\end{array}$ & $\begin{array}{l}\text { Strong pubescence } \\
\text { and the maximal } \\
\text { width of the } \\
\text { basitarsus is low } \\
\text { (sensu Gjershaug et } \\
\text { al., 2013) as in } \\
\text { lapponicus. }\end{array}$ & $\begin{array}{l}\text { Strong pubescence } \\
\text { and the maximal } \\
\text { width of the } \\
\text { basitarsus is low } \\
\text { (sensu Gjershaug } \\
\text { et al., 2013). }\end{array}$ & $\begin{array}{l}\text { Slight pubescence } \\
\text { and the maximal } \\
\text { width of the } \\
\text { basitarsus is high } \\
\text { (sensu Gjershaug } \\
\text { et al., 2013). }\end{array}$ & $\begin{array}{l}\text { Strong } \\
\text { pubescence and } \\
\text { the maximal } \\
\text { width of the } \\
\text { basitarsus is low } \\
\text { (sensu } \\
\text { Gjershaug et al., } \\
\text { 2013) as in } \\
\text { lapponicus. }\end{array}$ & $\begin{array}{l}\text { Strong } \\
\text { pubescence } \\
\text { and the } \\
\text { maximal width } \\
\text { of the } \\
\text { basitarsus is } \\
\text { low (sensu } \\
\text { Gjershaug et } \\
\text { al., 2013) as in } \\
\text { lapponicus. }\end{array}$ \\
\hline Tergite 1 & $\begin{array}{l}\text { Yellow with } \\
\text { some red and } \\
\text { black hairs }\end{array}$ & $\begin{array}{l}\text { Yellow with some } \\
\text { red and black hairs }\end{array}$ & $\begin{array}{l}\text { Yellow with some } \\
\text { red and black hairs }\end{array}$ & Black/red & $\begin{array}{l}\text { Yellow/ } \\
\text { red/black }\end{array}$ & $\begin{array}{l}\text { Yellow with } \\
\text { some red and } \\
\text { black hairs }\end{array}$ \\
\hline Tergite 4 & Yellow & Yellow & Yellow (pinkish) & Dark red & Yellow & Yellow \\
\hline Tergite 5 & $\begin{array}{l}\text { Yellow (higher } \\
\text { density) }\end{array}$ & Yellow & Yellow (pinkish) & Dark red & Yellow & Yellow \\
\hline
\end{tabular}




\begin{tabular}{|l|l|l|l|l|l|l|}
\hline Male & \multicolumn{2}{l|}{} & & \\
\hline Body size & $11-13 \mathrm{~mm}$ & $11-14 \mathrm{~mm}$ & $11-14 \mathrm{~mm}$ & $11-14 \mathrm{~mm}$ & $11-14 \mathrm{~mm}$ & $12 \mathrm{~mm}$ \\
\hline Tibia & Hairy & Very hairy & Hairy & Hairy & Hairy & Very hairy \\
\hline Color pattern & \multicolumn{2}{|l|}{} & & & \\
\hline Face & Yellow & Yellow & Yellow & Dark yellow & Yellow & Yellow \\
\hline $\begin{array}{l}\text { Collar/ } \\
\text { scutellar }\end{array}$ & $\begin{array}{l}\text { Yellow / large } \\
\text { yellow }\end{array}$ & $\begin{array}{l}\text { Yellow / large } \\
\text { yellow }\end{array}$ & $\begin{array}{l}\text { Yellow / large } \\
\text { yellow }\end{array}$ & Dark yellow /no & $\begin{array}{l}\text { Yellow / large } \\
\text { yellow }\end{array}$ & $\begin{array}{l}\text { Yellow / large } \\
\text { yellow }\end{array}$ \\
\hline Tergite 1 & Yellow & Yellow & Yellow & Black and red & Yellow & Yellow \\
\hline Tergite 4 & Yellow/red & Yellow/red & Yellow/red & Dark red & Red/yellow & Yellow/red \\
\hline Tergite 5 & Yellow/red & Yellow/red & Yellow/red & Dark red & Red/yellow & Yellow/red \\
\hline
\end{tabular}


970 Table 3. Taxonomic decision table with all criteria used for species delimitation. CLGS,

971 cephalic labial gland secretions; COI, cytochrome oxydase 1; bGMYC, the general mixed Yule-

972 coalescent model, PEPCK, phosphoenolpyruvate carboxykinase. Morphology indicates if a

973 taxon has a diagnostic morphological character (+/- means that morphology is/is not

974 diagnostic). Wing shape and size indicate if a taxon has a diagnostic wing shape and size (+/-

975 means that wing measures are/are not diagnostic). CLGS indicates if the taxon has/has not

976 diagnostic composition of CLGSs with different main compounds (+/- means that the taxon

977 has/ has not a specific CLGS composition. When the taxon shares CLGS composition with

978 other ones, the letters group together taxa that share similar CLGS. Phylogenetic analyses

979 indicate if a taxon forms a strongly supported monophyletic group (+/- means that the taxon

980 is/is not a monophyletic group). When the taxon is not a distinct monophyletic group, the letters

981 group together taxa included in the same monophyletic group (A). LS= low supported

982 differentiation. NA = not assessed.

\begin{tabular}{|c|c|c|c|c|c|c|}
\hline Former taxonomic status & $\begin{array}{l}\text { Morphology } \\
\text { (diagnostic character) }\end{array}$ & $\begin{array}{l}\text { Wing } \\
\text { shape / } \\
\text { size }\end{array}$ & CLGS & $\begin{array}{l}\text { COI } \\
\text { gene/bGMYC }\end{array}$ & PEPCK gene & Proposed taxonomic status \\
\hline B. sylvicola, Alaska, Yukon & $-(\mathrm{A})$ & $-(\mathrm{A}) /-$ & $-(\mathrm{A})$ & $+/-$ & $-(\mathrm{A})$ & B. lapponicus sylvicola \\
\hline Unnamed species Alaska & + & $+/-$ & + & $+/+$ & + & B. interacti sp. nov. \\
\hline B. bimaculatus & + & NA & + & $+/+$ & + & B. bimaculatus \\
\hline B. ephippiatus & + & NA & + & $+/+$ & + & B. ephippiatus \\
\hline B. melanopygus & + & NA & NA & $+/+$ & + & B. melanopygus \\
\hline B. glacialis & + & $\overline{\mathrm{NA}}$ & $\mathrm{NA}$ & $+/+$ & NA & B. glacialis \\
\hline
\end{tabular}

983 


\section{Supporting information}

986 Table S1. List of all specimens analyzed. Sample code refers to the sample labels used in 987 different analyses. COI and PEPCK are the GenBank accession numbers for each sample.

988 Table S2. Summary of data matrix of cephalic labial gland secretions (with minimum, median 989 and maximum of relative concentration of each compound), list of the identified compounds 990 and IndVal analysis with species-specific compounds. Unknown $\mathrm{x}$ are undetermined 991 compounds.

992 


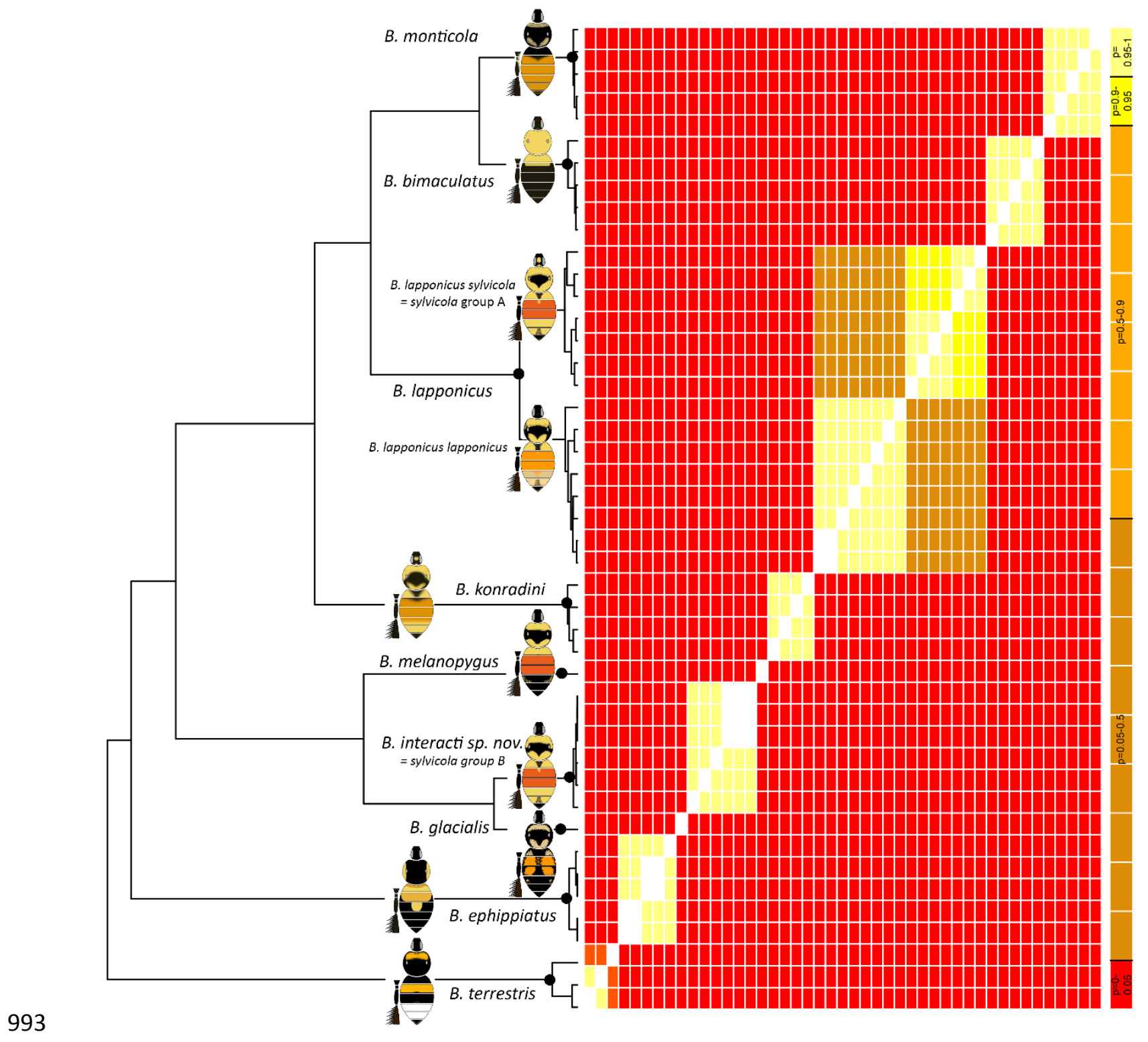




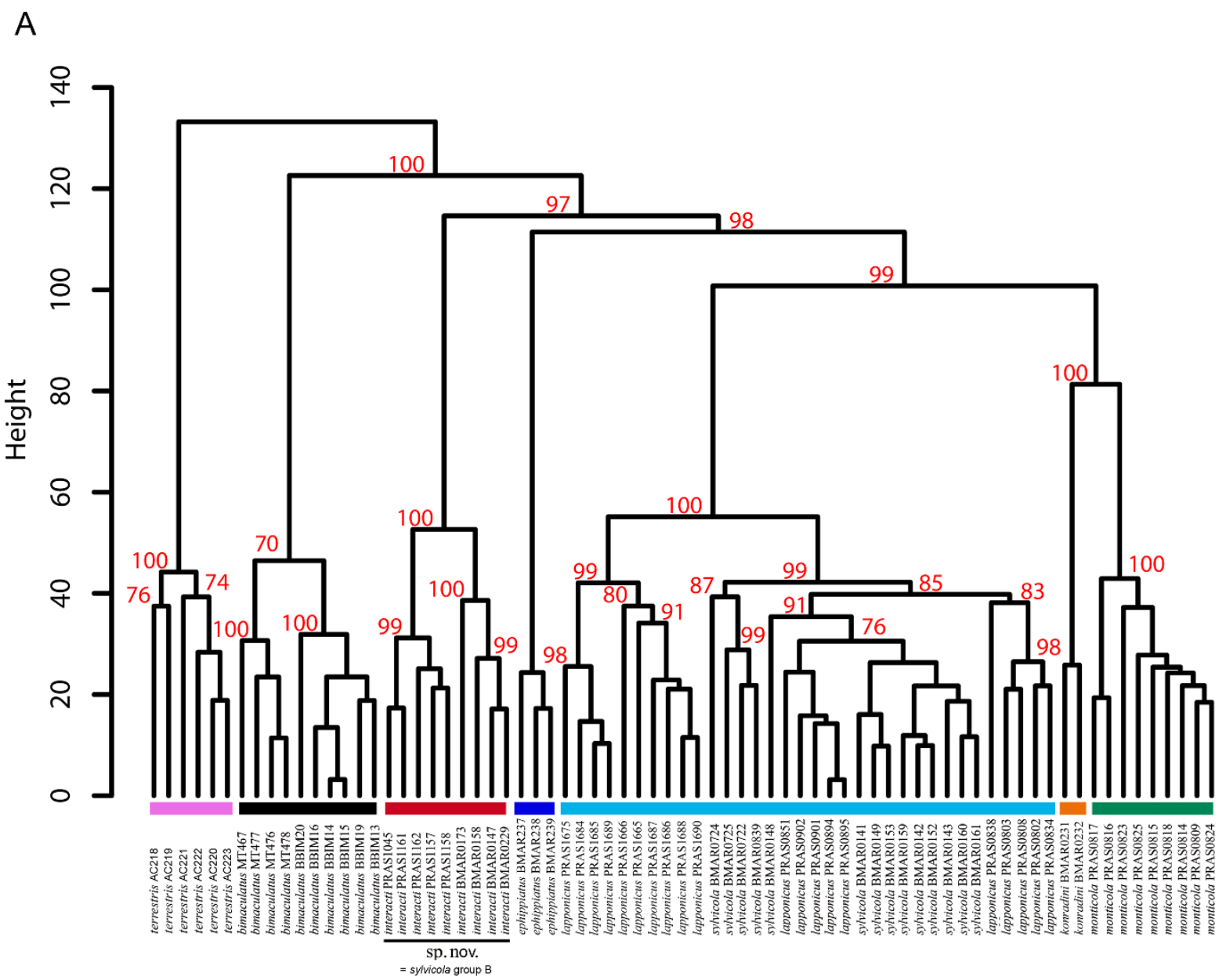

B
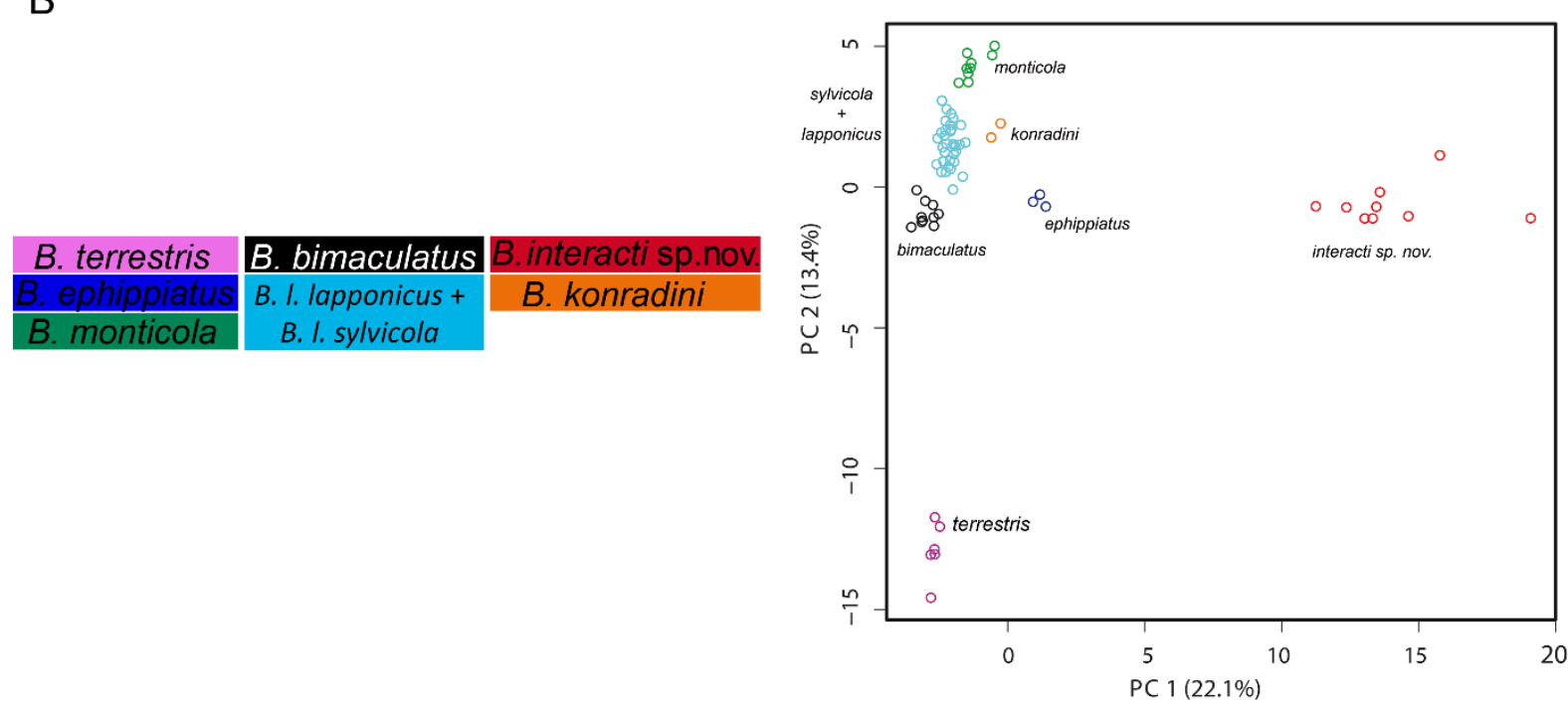


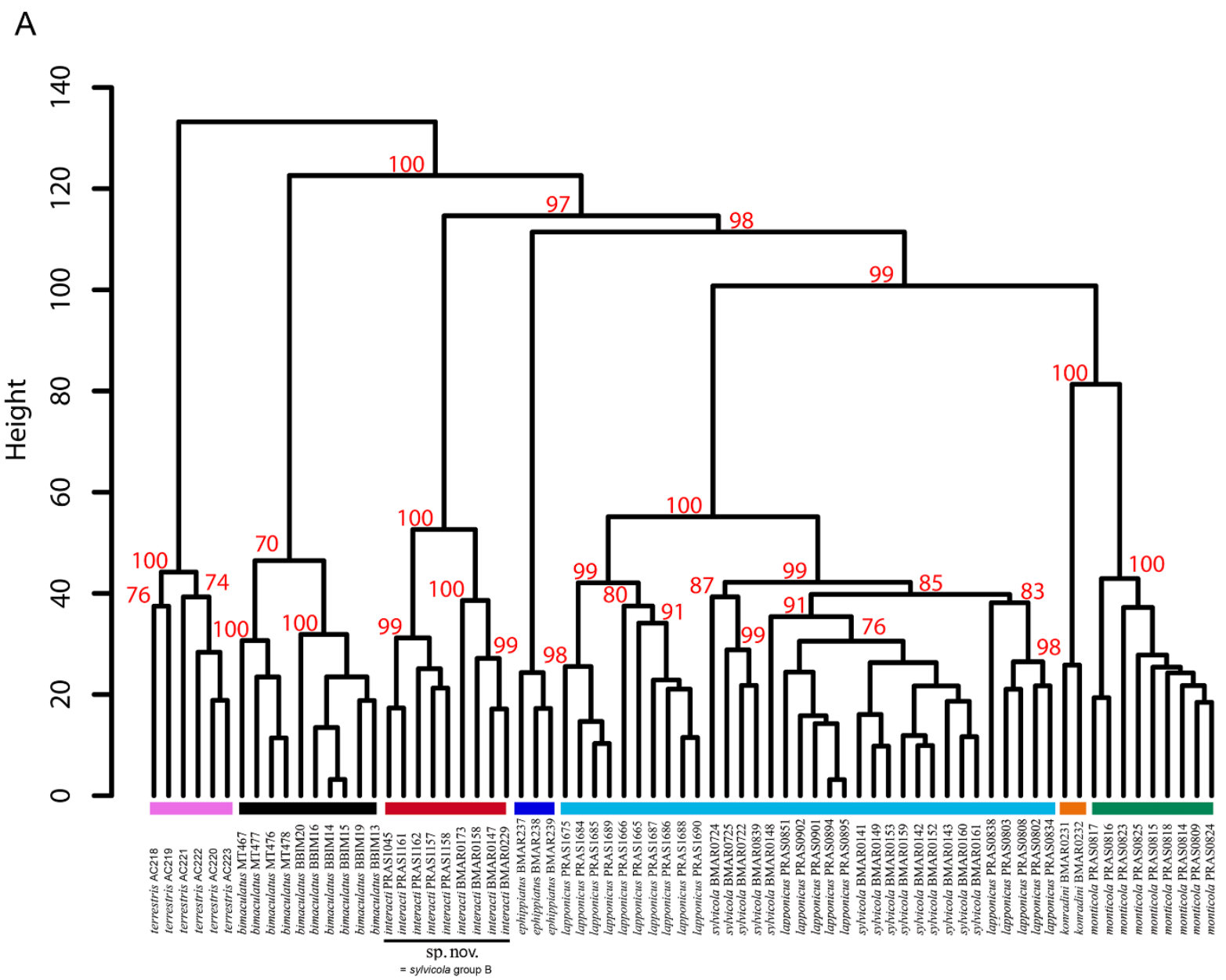

B
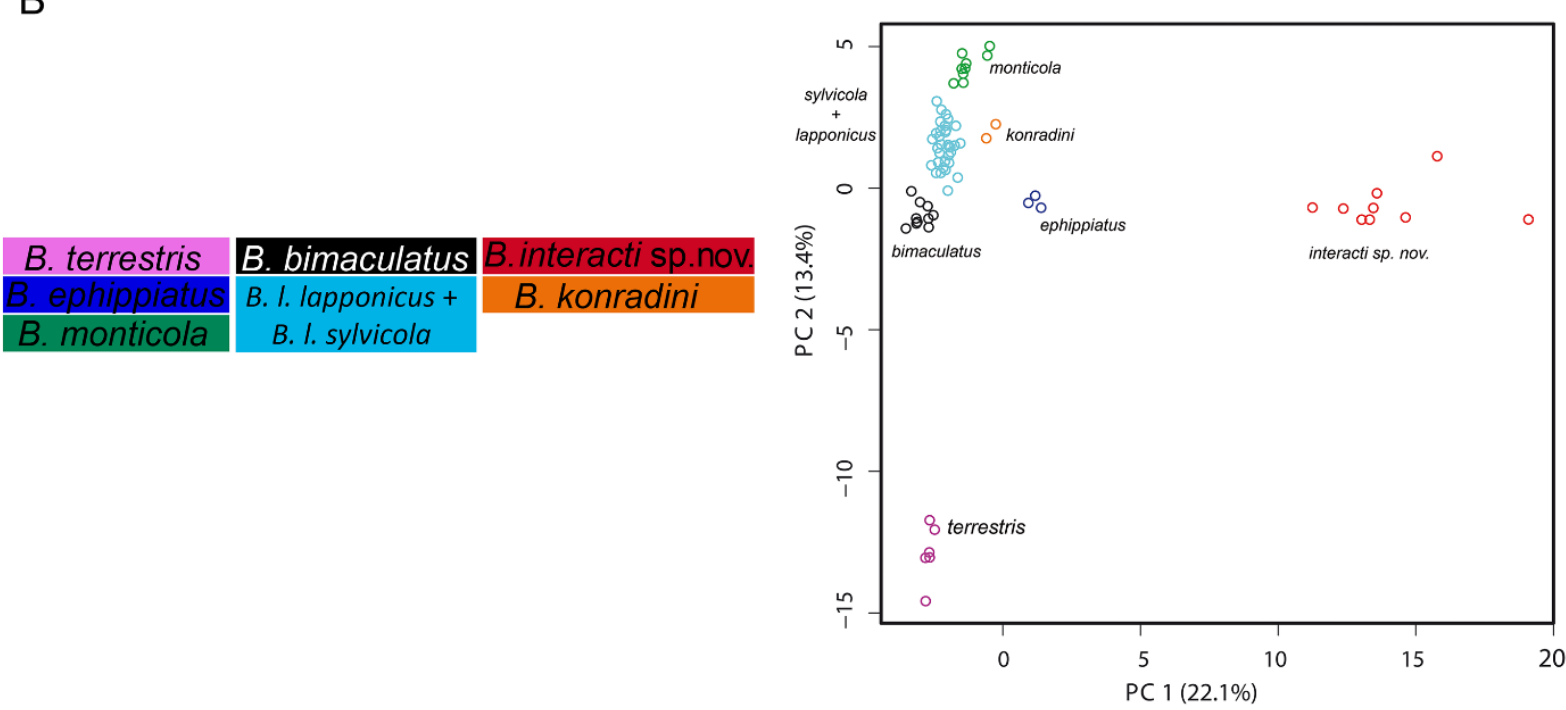


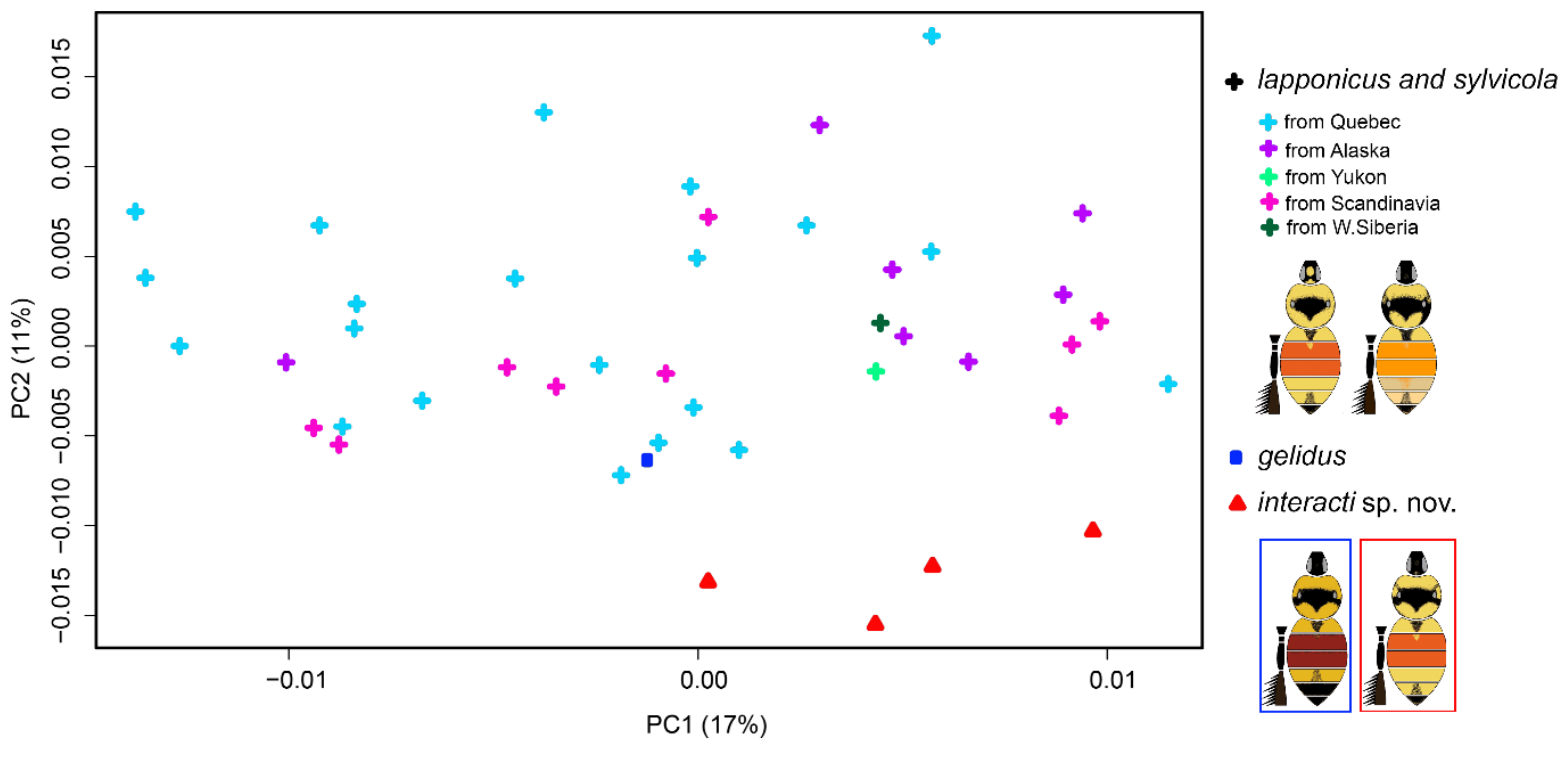




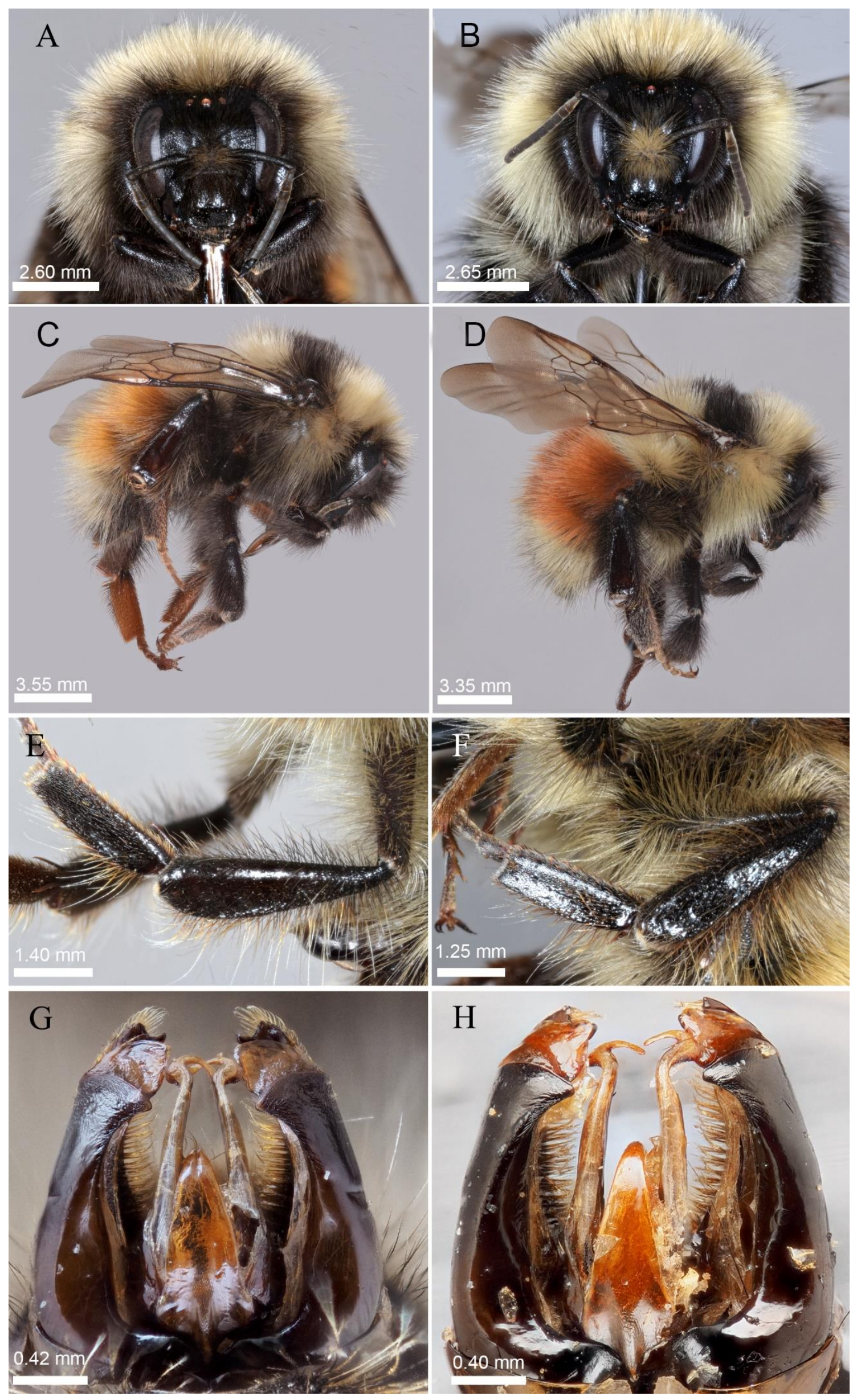



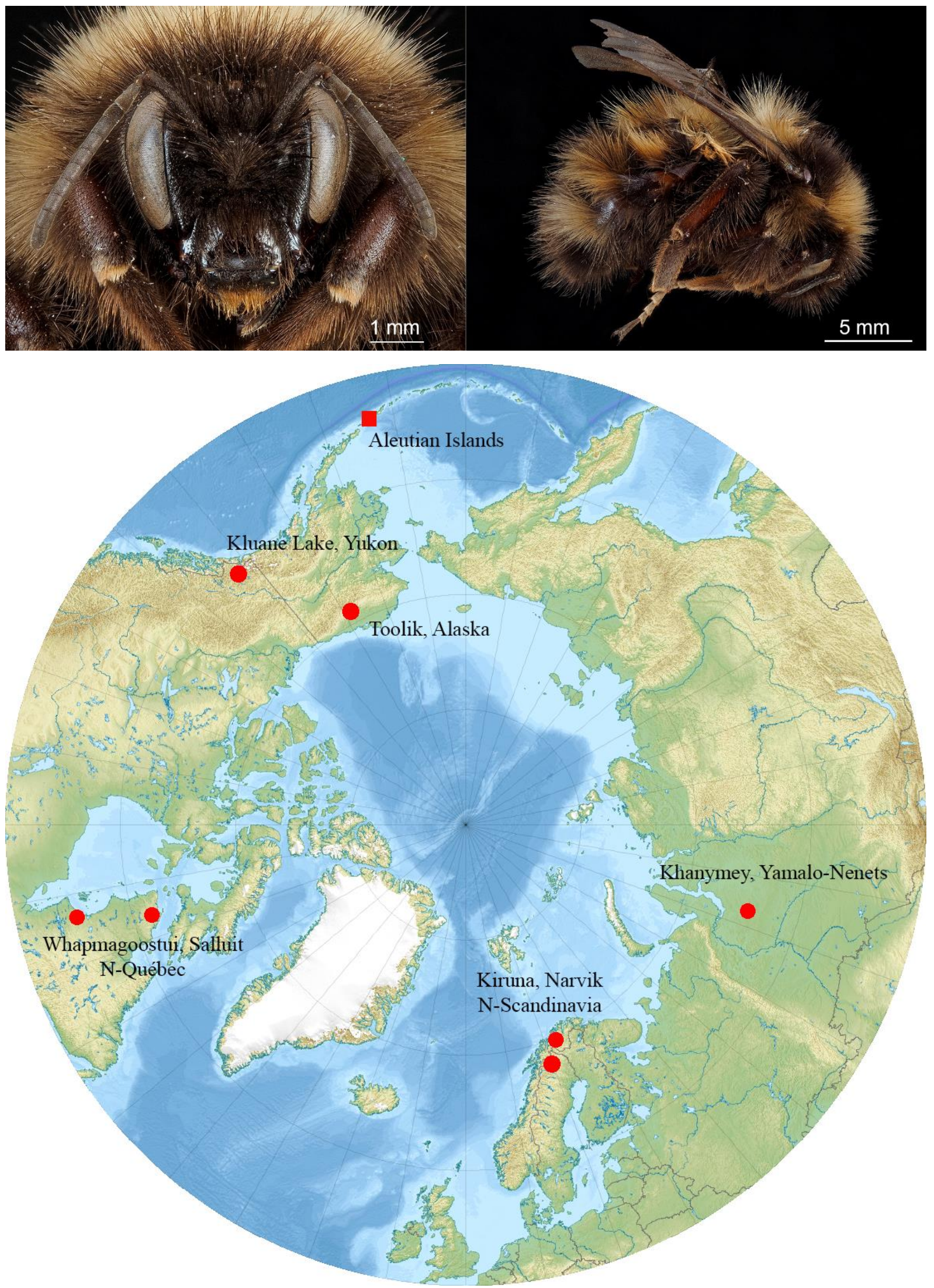


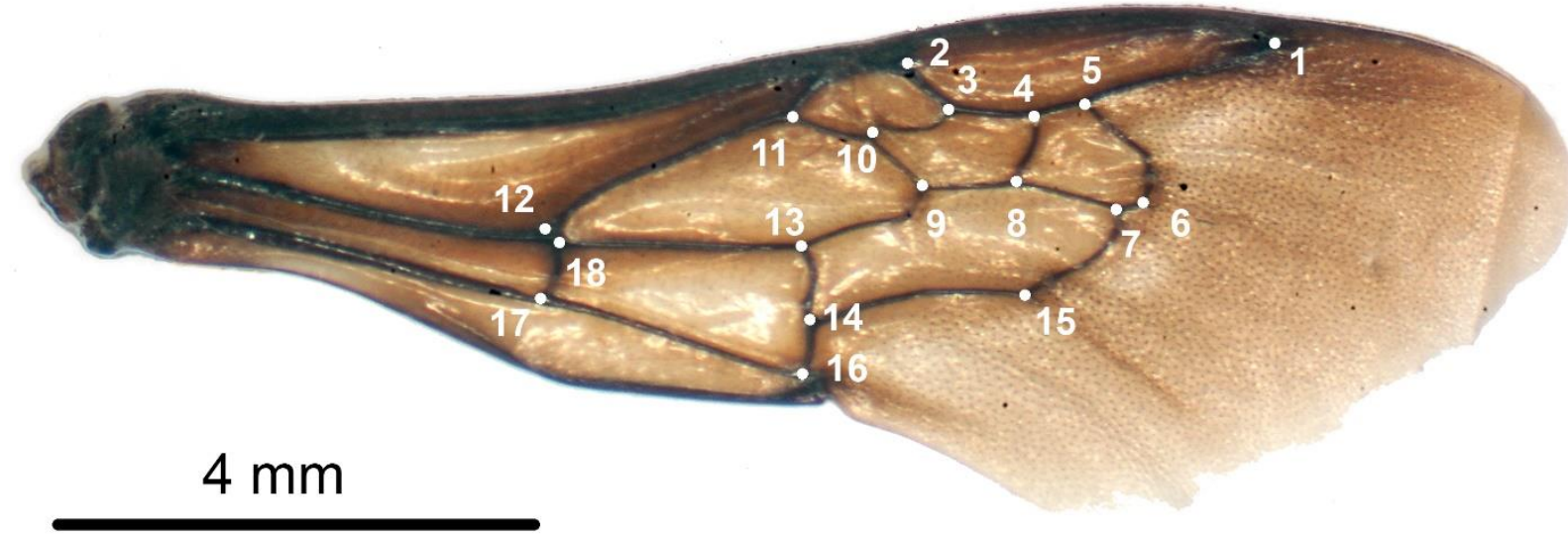

1000
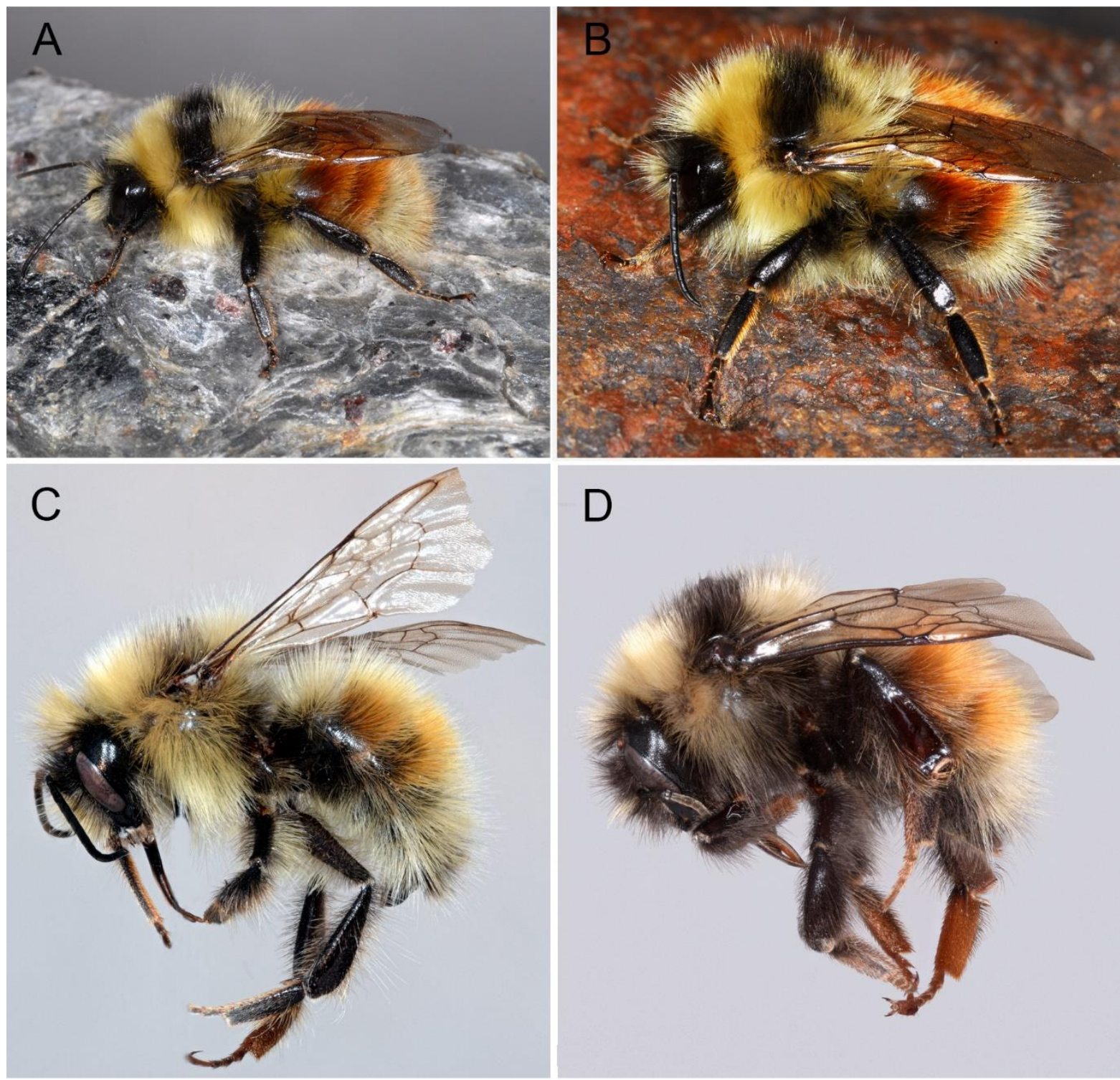

D

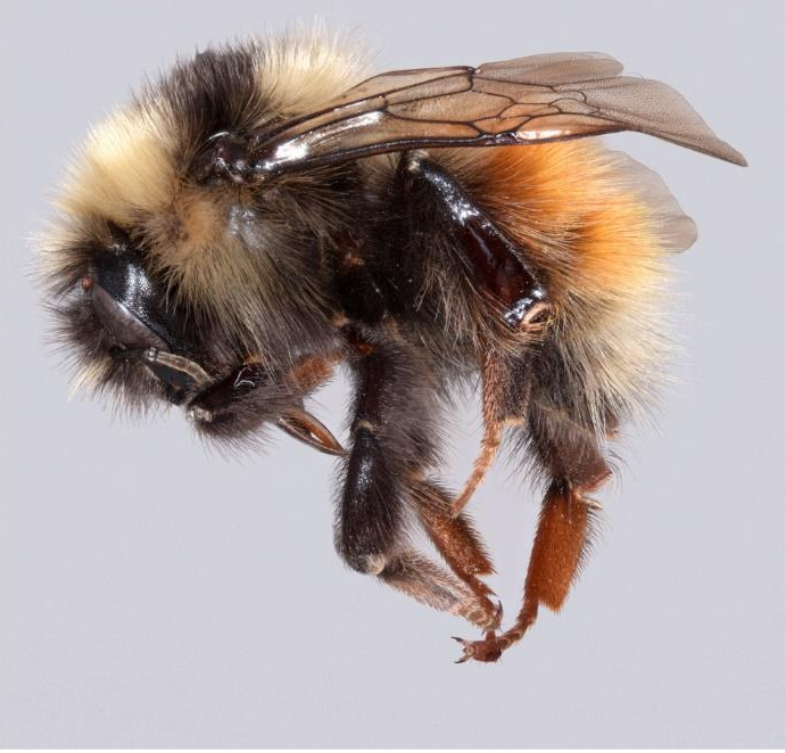



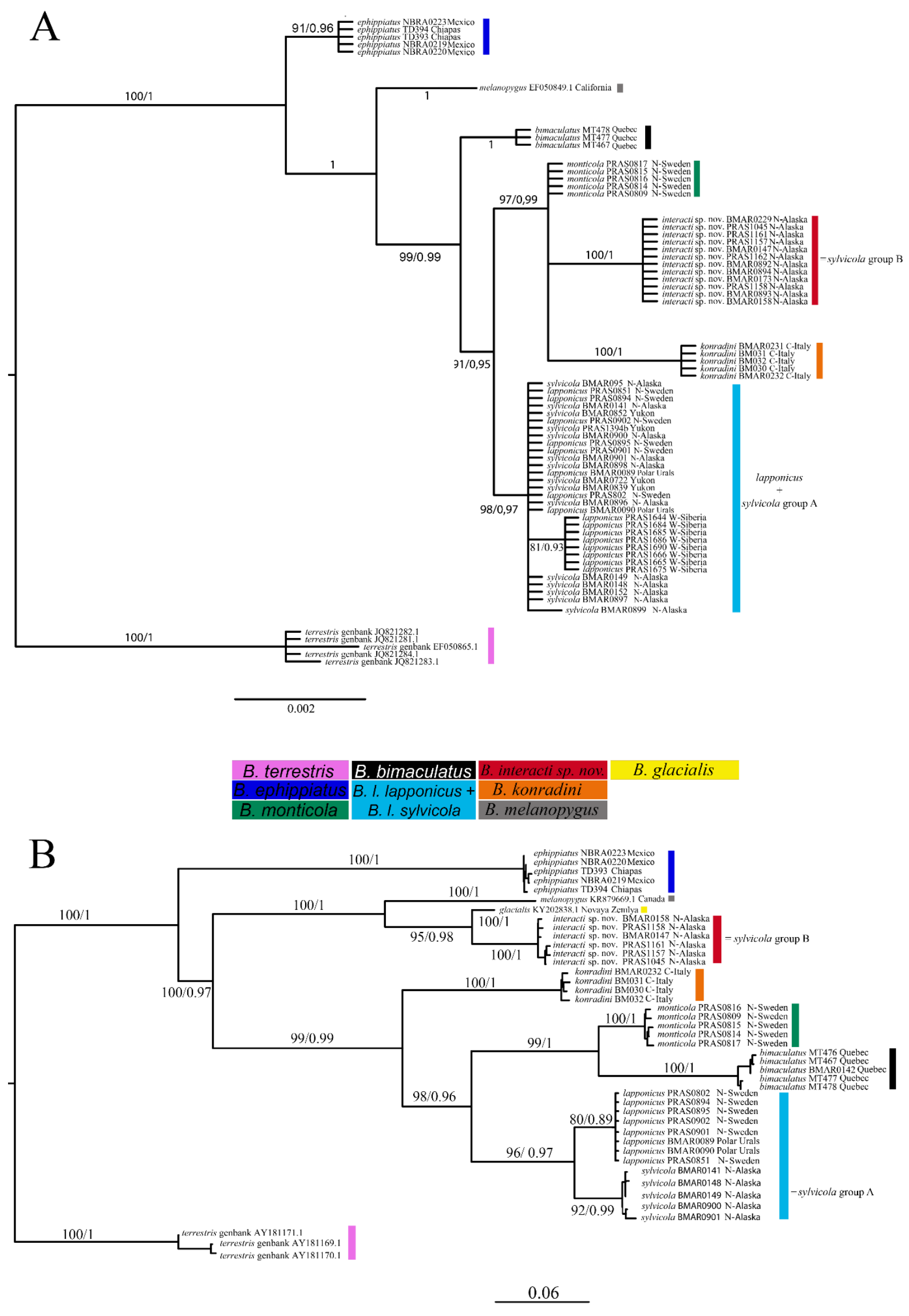